DOI: $10.1515 /$ linpo-2015-0003

\title{
Toward a formal model of semantic change: A neo-Reichenbachian approach to the development of the Vedic past tense system*
}

\author{
Eystein Dahl
}

UiT - The Arctic University of Norway, eda021@post.uit.no

\begin{abstract}
Eystein Dahl. Toward a formal model of semantic change: A neo-Reichenbachian approach to the development of the Vedic past tense system. The Poznań Society for the Advancement of Arts and Sciences, PL ISSN 0079-4740, pp. 41-76

This paper explores some ways in which a neo-Reichenbachian time-relational framework can be applied to diachronic data. The target language of this study is Vedic Sanskrit, the language of the sacred texts of Hinduism. The main focus of the paper concerns the evolution of the Vedic past tense system, which at the beginning of the Vedic tradition is aspect-based and later develops into a system where temporal remoteness and evidentiality distinctions determine the distribution of the past tense categories. This language therefore offers a particularly intriguing data set for exploring the diachronic relationship between aspect, proximal tense and evidentiality, a field of diachronic semantics which has only received limited attention in the research literature.
\end{abstract}

Keywords: Vedic Sanskrit, semantic change, aspect, tense, temporal remoteness, evidentiality

\section{Introduction}

The last decades have witnessed a growing appreciation of the relevance of historical data, particularly diachronic semantics for linguistic theory. For example, the cross-linguistically oriented grammaticalization research has yielded large-scale studies of grammatical change like, for instance, Bybee et al. (1994), which have significantly contributed to our understanding of the universal aspects of the semantic development of Tense, Aspect and

* On its thorny road to publication, this paper has benefited from comments from audiences in Freiburg, Pavia, Rome and Tromsø. I am especially grateful to Silvia Luraghi, Anna Giacalone Ramat, Paolo Di Giovine, Alessandro De Angelis and Peter Svenonius for their insightful remarks. Terje Lohndal read a previous version of the paper and his extremely useful and constructive feedback has been of great help in revising the paper. I also profited from the suggestions given by no less than three anonymous referees, two of which were appointed by Lingua Posnaniensis and one of which was appointed by Brill in connection with a book project I was editing that was later abandoned, in large part because of the stern critique raised by this very referee. I feel, however, especially indebted to this last referee because her (or his) remarks made me realize that the project had no future and thereby saved me lots of time and frustration. Evidently, all remaining errors and shortcomings remain my own responsibility. 
Mood (TAM) categories (cf. also Bybee \& Dahl 1989). While there has been a growing interest in diachronic semantics within functionally and typologically oriented frameworks in the last years, in the same period there has been a growing interest in the study of TAM semantics within the tradition of formal semantics which has generated many new and exciting insights into these matters. However, the majority of the research conducted within more formally oriented approaches has a more or less strictly synchronic scope, focusing almost exclusively on present-day languages (cf. e.g. Klein 1995; Kratzer 1998; Portner 2007; Smith 1997) or synchronically oriented analyses of historical languages (cf. e.g. Kiparsky 1998; 2005; Bary 2009; and Dahl 2010). Notable exceptions to this general trend include von Fintel (1995), Eckardt (2006) and Schaden (2009; 2012), that deal with different semantic dimensions of grammaticalization processes from a formally oriented perspective. The present paper has an analogous aim, attempting to explore the descriptive potential of formally oriented semantic theory in the context of diachronic TAM processes that in some respects resemble characteristic instances of grammaticalization but in other respects diverge somewhat from this type of change. Specifically, I explore the development of the Vedic Aorist, Imperfect and Perfect within a multidimensional time-relational framework of the type first proposed by Hans Reichenbach (1947) and developed further by Klein (1995), Kratzer (1998) and others and in what ways a framework of this type may be in need of modification in order to accommodate the diachronic data from Vedic. I would like to emphasize from the outset that this paper primarily aims at exploring the diachronic capacity of a formally oriented framework of the type just mentioned. Some readers may therefore find the empirical part too meager. I refer to Dahl $(2009 b ; 2013 ; 2014)$ for a more detailed elaboration of the philological and empirical dimensions of the present discussion.

The paper is organized in the following manner. Section 2 contains some philological background information, including a survey of chronological stages of Vedic (2.1), an overview of the Early Vedic past tense system (2.2) and an outline of the Late Vedic past tense system (2.3). Section 3 outlines the main theoretical assumptions on which the remainder of this paper is based, including an outline of the neo-Reichenbachian framework adhered to in the paper (3.1) and a formalization of the idea that tense and aspect categories may be regarded as universal prototypes (3.2). Section 4 contains a brief discussion of the development of the Vedic Aorist Indicative (4.1), the Perfect Indicative (4.2) and the Imperfect (4.3). Section 5 discusses the main findings of the paper and Section 6 contains a conclusion and outlook.

\section{Philological preliminaries}

\subsection{Chronological stages of Vedic}

Before turning to the main topic of this paper, a few brief philological remarks are necessary. First, Vedic and Classical Sanskrit represent the two oldest stages of the IndoAryan branch of the Indo-Iranian languages which belong to the Indo-European language family. In the present context, Vedic is used to refer to the language of the so-called Vedas and their commentaries, the sacred texts of Hinduism. As the historical context of the Vedic texts to a large extent remains opaque, any attempt of establishing an absolute chronology 
for these texts remains stipulative at best. According to one widespread view the earliest extant text, the Rigveda, had attained the form known to us somewhere around $1200 \mathrm{BC}$. The latest Vedic texts are probably not much younger than 600 BC. Classical Sanskrit, on the other hand, is understood as the language described by the native Indian grammarian Pānini. Again an absolute chronology is hard to establish, but a not implausible date for his comprehensive description of Sanskrit, the Așthāahyāy $\bar{\imath}$, lies somewhere around 600 BC. Our absolute chronological framework thus covers about 6 centuries, from approximately 1200 to $600 \mathrm{BC}$.

The extant corpus of Vedic texts is rather voluminous and one may distinguish at least five distinct chronological stages of Vedic. These are summarized in $1 \mathrm{~b}$ and will constitute the diachronic framework in the following discussion. I wish to point out, however, that I run a certain risk of circularity here, as some of the patterns of change about to be discussed are standardly used as a criterion for distinguishing between some of the various chronological stages. In other words, the relative chronology on which the diachronic framework of the present account is based at least in part is construed on the basis of certain phenomena, which at the same time represent the object of inquiry. Although this fact to some extent may be taken to weaken the validity of the results presented in this paper, it is not clear to me that this circularity necessarily is pernicious, as the relevant patterns of change only represent one of several criteria which constitute the basis for the relative chronology. A summary of the chronological stages of Vedic and the most important sources for each period is given in Table 1 (cf. e.g. Witzel 1989; 1995).

Table 1. Chronological stages of Vedic

\begin{tabular}{l|l}
\hline Early Vedic & The language of the Rigveda $(\mathrm{RV})^{1}$ \\
\hline Early Middle Vedic & $\begin{array}{l}\text { The language of the mantra parts of the Atharvaveda (AVŚ, AVP), } \\
\left.\text { the Yajurveda (VSM, VSK, TS }{ }^{\mathrm{M}}, \mathrm{MS}^{\mathrm{M}}, \mathrm{KS}^{\mathrm{M}}\right) \text { and the Rigvedakhilāni } \\
(\mathrm{RVK})\end{array}$ \\
\hline Middle Vedic & $\begin{array}{l}\text { The language of the oldest Vedic prose texts (e.g. TS }{ }^{\mathrm{P}}, \mathrm{MS}^{\mathrm{P}}, \mathrm{KS}^{\mathrm{P}}, \mathrm{AB} \\
\text { I-V, TB I-III 9, TA III-VI, ŚBM VI-X 5) }\end{array}$ \\
\hline Late Middle Vedic & $\begin{array}{l}\text { The language of the younger Vedic prose texts (e.g. AB VI-X, ŚBM } \\
\text { I-V, TB III 10-12, JB, KB) }\end{array}$ \\
\hline $\begin{array}{c}\text { Late Vedic } \\
\approx\end{array}$ & $\begin{array}{l}\text { The language of the youngest Vedic prose texts (e.g. BĀU }=\text { ŚBM X } \\
\text { 6.4-6.5.8, XIV 4.1-9.4) }\end{array}$ \\
\hline
\end{tabular}

At this juncture it should be noted that there is a non-negligible difference between the Early Vedic and Early Middle Vedic sources, on the one hand, and the Middle Vedic, Late Middle Vedic and Late Vedic sources, on the other. Simplifying matters somewhat, the former consists exclusively of metrical hymns, prayers, incantations and magic spells whereas the latter mainly comprises prose texts, either describing some part of a ritual or explaining a part of the ritual by appealing to some mythological story which is of obviously created ad hoc or adapted for explanatory purposes. The fact that the various chronological stages

1 It should be noted that the Rigveda does not constitute a chronologically unitary corpus, as it partly contains very old material as well as relatively recent material. While I refrain from a discussion of its different chronological stages, I wish to draw attention to the fact that it contains some hymns which for various reasons rather belong to Early Middle Vedic than to Early Vedic proper. I refer to Kulikov (2013) for a different chronological framework. 
of Vedic are represented by fundamentally different text types raises a number of more or less fundamental interrelated methodological or heuristic problems, some of which may be worth mentioning here. Specifically, it is well known that the use of a given TAM category can differ substantially from one type of text to another. One might therefore expect the use of the Vedic past tenses in a collection of metrical hymns like the Rigveda to differ in significant respects from the use of the same categories in a Late Vedic prose text. It is therefore not immediately transparent to what extent the different primary data sets can be directly compared and, as a consequence, it is unclear how one can establish whether there are any typologically significant changes in the Vedic tense/aspect system through the various stages of the language. Moreover, as far as aspect distinctions are concerned, the well established distinction between imperfective and perfective aspect is particularly pellucid in narrative discourse (cf. e.g. Smith 2003), a text type which is hardly represented at all in the Early Vedic and Early Vedic sources. However, as argued in Dahl (2010) there is reason to believe that this problem can be overcome. Specifically, once one has acknowledged that the textual sources contain a restricted and quirky set of primary linguistic data, one may proceed to ask what the behaviour of a given grammatical category in a text of the type at hand can reveal about its semantics. Typological studies like Dahl (1985) and Smith (1997) have established that semantically similar grammatical categories have nearly identical clusters of lexically and contextually determined readings across the languages of the world. This fact allows for entertaining a number of fairly precise hypotheses about the underlying semantics motivating a given set of discourse functions associated with a given morphosyntactic category in a given language at a given time. From this perspective, the readings associated with a given category constitute important heuristic cues for delimiting its semantic properties. This idea will be elaborated on in Section 2. In the following I provide a brief outline of the most salient features of the past tense system in Early Vedic (Section 1.1) and in Late Vedic (Section 1.2). A more elaborate investigation of the development of the past tense categories through the different stages of Vedic is found in Section 3 below.

\subsection{Outline of the Early Vedic past tense system}

In Early Vedic, we find three morphologically distinct categories which systematically show past time reference, the so-called Imperfect, Aorist Indicative and Perfect Indicative which are primarily distinguished by means of different inflectional stems, the Present, Aorist and Perfect stems. ${ }^{2}$ This system remains virtually intact through the various stages of Vedic. The traditional indigenous and western descriptions of Vedic list verbal lexemes as roots which form the basis of these inflectional stems. The inflectional stems either consist of the simple root or are derived from the root by various morphological processes, above all reduplication and suffixation. By way of illustration, consider the forms given in Table 2.

${ }^{2}$ Note that a variety of other verbal grammatical categories are also occasionally used with past time reference, notably the Present Indicative and the Injunctive; however, as this reading only represents one among several temporal readings of both of these categories, they will not be systematically dealt with in the following discussion. 
Table 2

\begin{tabular}{|c|c|c|}
\hline \multicolumn{3}{|c|}{$B H A V^{\prime}$ - 'become, be' } \\
\hline Present & Aorist & Perfect \\
\hline $\begin{array}{l}\text { bhav-a- } \\
\text { abhavat }\end{array}$ & $\begin{array}{l}b h \bar{u}- \\
a b h \bar{u} t\end{array}$ & $\begin{array}{l}\text { babhūv- } \\
\text { babhūva }\end{array}$ \\
\hline \multicolumn{3}{|c|}{ CAR-'move' } \\
\hline $\begin{array}{l}\text { car-a- } \\
\text { acarat }\end{array}$ & $\begin{array}{l}\text { cariș- } \\
\text { acarìt }\end{array}$ & $\begin{array}{l}\text { cacār- } \\
\text { cacāra }\end{array}$ \\
\hline
\end{tabular}

The simplified synopsis given in Table 1 illustrates some of the most characteristic morphological stem-formation processes in Vedic. It also suffices to show how Imperfect forms like abhavat 'became, was' or acarat 'moved, was moving', Aorist Indicative forms like abhüt 'became' or acarìt 'moved, has moved' and Perfect Indicative forms like babhūva 'has become, has been' and cacāra 'has moved, has been moving' differ formally from each other.

Although the exact semantic properties of the Early Vedic past tense categories remain somewhat disputed, a recent study (Dahl 2010) has made a case for the claim that their distribution in the Rigveda is determined by the fact that they have different aspectual properties which can be traced back to the underlying primary stems. For example, the Imperfect is regarded as a general past tense with a neutral aspectual value, implying that it is radically underspecified regarding aspectual reference as reflected in the fact that it is compatible with perfective-like as well as imperfective-like readings (cf. Section 3 for discussion). This may be illustrated by the examples in (1).

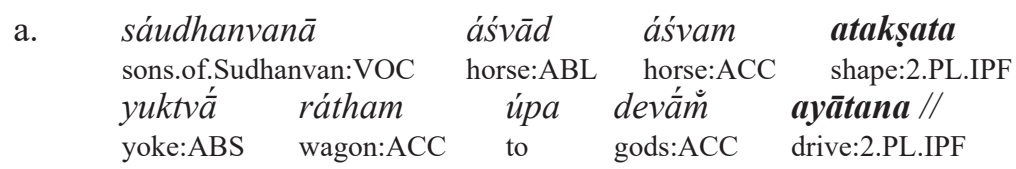

'O sons of Sudhanvan, from a horse you created a (second) horse. Having yoked the wagon, you drove to the gods' (RV I 161.7cd after Dahl 2010: 192)

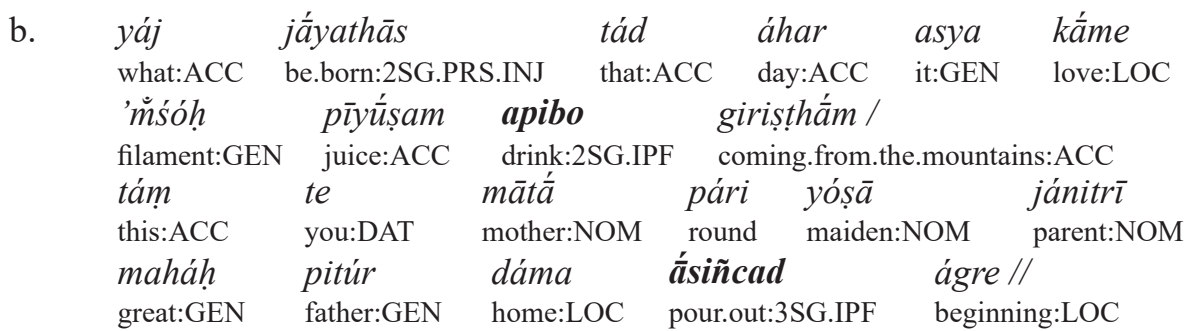

'On the day when you were born you voluptuously drank nectar of the plant which comes from the mountains. Your mother, the young maiden, was pouring it abundantly out for you in the house of your great father for the first time' (RV III 48.2 after Dahl 2010: 203-204)

In (1a), the Imperfect form atakșata 'created' denotes a situation which is represented as being completed prior to the situations denoted by the absolutive yuktvá 'having yoked' and the Imperfect form ayätana 'drove'. In contrast, the Imperfect forms apibas 'you drank, were drinking' appears to denote a situation which is temporally overlapping with the situ- 
ation denoted by the following Imperfect ásiñcat 'poured, was pouring'. In cases of the former type, the Imperfect may be said to have a perfective-like meaning, in cases like that illustrated in (1b) it seems to have an imperfective-like meaning.

The Early Vedic Aorist Indicative, on the other hand, is taken to represent a marked perfective category, as it primarily shows perfective-like readings. The examples in (2) may be cited as an illustration.

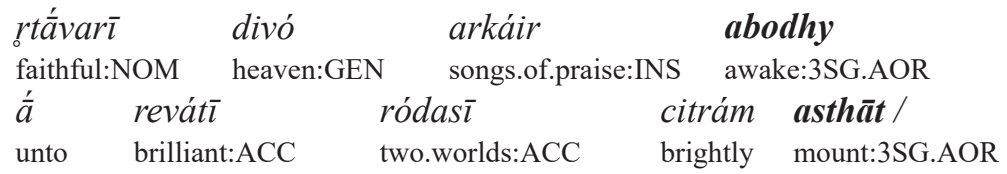

'The faithful (daughter) of heaven has awoken to (our) songs of praise. Brightly she has climbed unto the brilliant two worlds' (RV III 61.6ab after Dahl 2010: 272)

b.

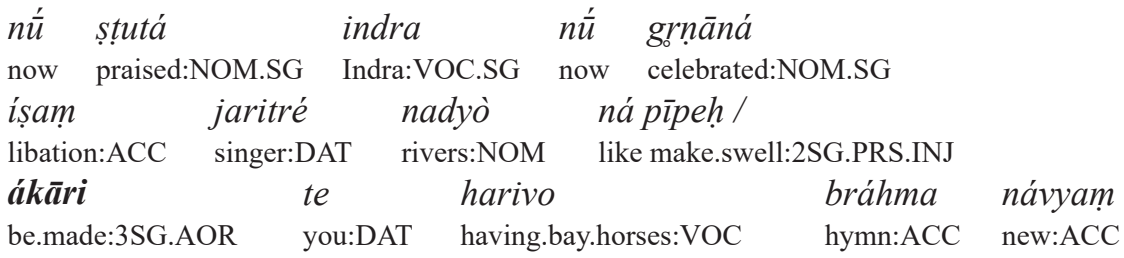

'Now you have been praised, now you have been celebrated, you have made the libation swell for the singer like rivers. A new hymn has been made for you, o you whose horses are bay' (RV IV 16.21a-c after Dahl 2010: 265-266)

$\begin{array}{lllll}\text { c. anyó } & \text { anyám } & \text { ánu grbhn̄āty enor } \\ \text { another:NOM } & \text { another:ACC after take:3.SG.PRS the.two:GEN } \\ \text { apám } & \text { prasargé } & \text { yád ámandișātām/ } \\ \text { waters:GEN } & \text { outburst:LOC } & \text { when be.delighted:3DU.AOR }\end{array}$

'One of the two grasps the other from behind, when they have become exhilarated in the discharge of the waters' (RV VII 103.4 after Jamison 1993: 140)

These examples illustrate that Aorist Indicative forms are used to express that a situation has been completed prior to another situation in the past (2a) or to express that a situation has taken place just before the moment of speech (2b). Finally, the example in (2c) shows that Aorist Indicative forms of atelic predicates are sometimes used with a distinctively inchoative-ingressive reading, that is, to focus the entry into a state or situation. All of these readings are characteristic of perfective categories.

The Early Vedic Perfect Indicative seemingly has roughly the same semantic properties as the English Present Perfect. Consider the examples in (3).

\begin{tabular}{llll} 
(3) a. & asyá & pītváa & mádānām \\
it:GEN & drink:ABS & intoxicating.potions:GEN \\
& índro & vrtráni & apratí \\
Indra:NOM & enemies:ACC & without.opponents:NOM \\
& jaghána & jaghánac & \multicolumn{2}{c}{$c a$ nú } \\
smite:3.SG.PRF & smite:3.SG.PRF.SBJ and now
\end{tabular}

'Having drunk of its intoxicating potions Indra who is without opponents has smitten enemies and will also now smite enemies' (RV IX 23.7) 


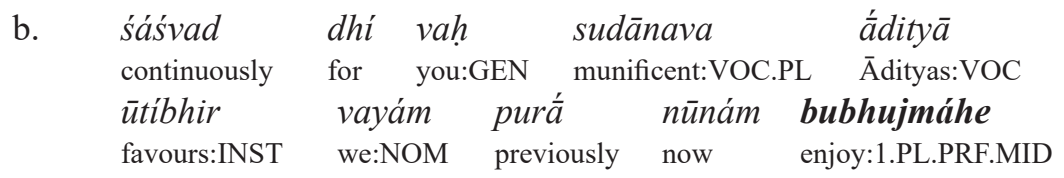

'For we have continuously been enjoying ourselves with your favors, o munificent Ādityas, formerly (and) now' (RV VIII 67.16)

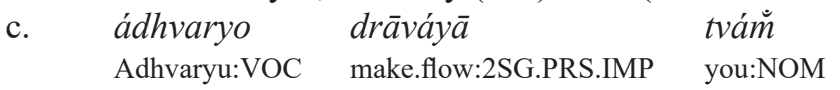

$\begin{array}{lll}\text { sómam indrah̆ } & \text { pipāsati/ } \\ \text { soma:ACC Indra:NOM } & \text { drink:DESID.3SG.PRS } \\ \text { úpa nūnám } & \text { yuyuje } & \text { vr'șanāa } \\ \text { unto now } & \text { yoke:3SG.PRF } & \text { bulls:ACC }\end{array}$

$\begin{array}{lllll}\text { hárī } & \dot{a} & c a & \text { jagāma } & \text { vrtrahó } / / \\ \text { bay:ACC } & \text { to } & \text { and } & \text { come:3SG.PRF } & \text { Vrrtrakiller:NOM }\end{array}$

'Adhvaryu, you let the soma flow! Indra wishes to drink. Now the Vrrtrakiller has yoked his two bay bull-like ones and has come hither' (RV VIII 4.11)

These examples suffice to illustrate that the Early Vedic Perfect Indicative is sometimes used to express that the situation denoted by the predicate has occurred an indefinite number of times prior to the time of speech (3a), that a situation of the type denoted by the predicate has been going on for some time in the past and still holds at the time of speech ( $3 \mathrm{~b})$ and that a given situation has been completed prior to and that the result is still relevant at the time of the utterance $(3 \mathrm{c})$. These readings correspond to the so-called existential, universal and resultative readings of the English Present Perfect (cf. Kiparsky 1998, 2002 for discussion and references). ${ }^{3}$ The examples in (1) through (3) illustrate that the Early Vedic Imperfect, Aorist Indicative and Perfect Indicative have distinct and yet possibly overlapping temporal and aspectual properties.

\subsection{Outline of the Late Vedic past tense system}

In the Late Vedic prose texts we find a past tense system which appears to differ in typologically significant respects from the Early Vedic past tense system. Notably, as discussed in somewhat more detail in Dahl (2012), the Late Vedic Aorist Indicative is associated with a recent or immediate past time reference, while the Imperfect is generally restricted to remote past contexts. Both of these categories mainly appear to be used in discourse contexts where the speaker refers to situations he himself has witnessed. In contrast, the Perfect Indicative is used in context referring to situations outside the speaker's own sphere of experience. Consider the following examples:

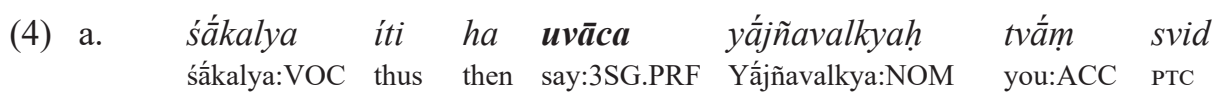

\footnotetext{
${ }^{3}$ Consider the following examples:

He has visited France (once/several times) [existential]

He has lived in Germany since 2005 (and still does) [universal]

He has come (and is here now) [resultative]
} 


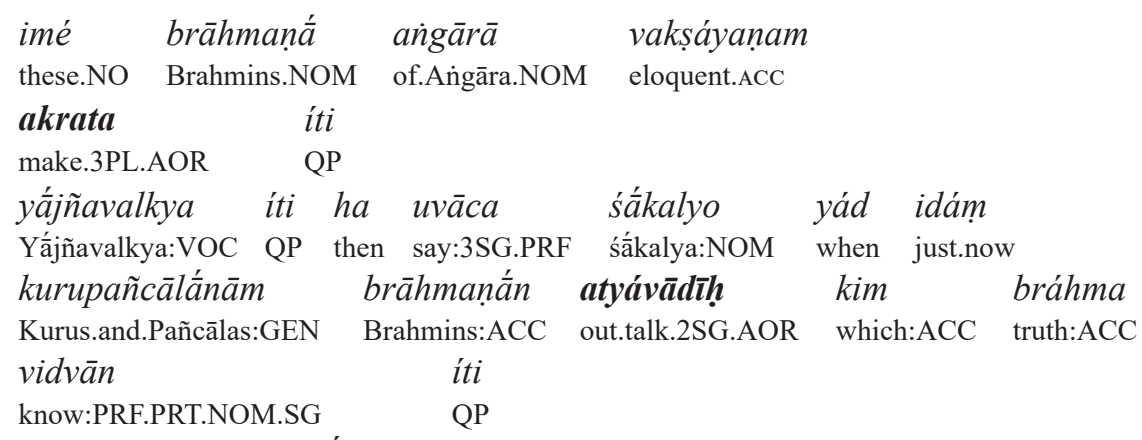

'Yājñavalkya said: "Śākalya, it is clear that the Brahmins from Angāara have made you eloquent." Śākalya said: "Tell me, Yājñavalkya, which truth did you know when you out-talked the Brahmins of Kuru and Pañcāla just now?"' (ŚBM XIV 6.9.19-20 = BĀU III 9.19)

b.

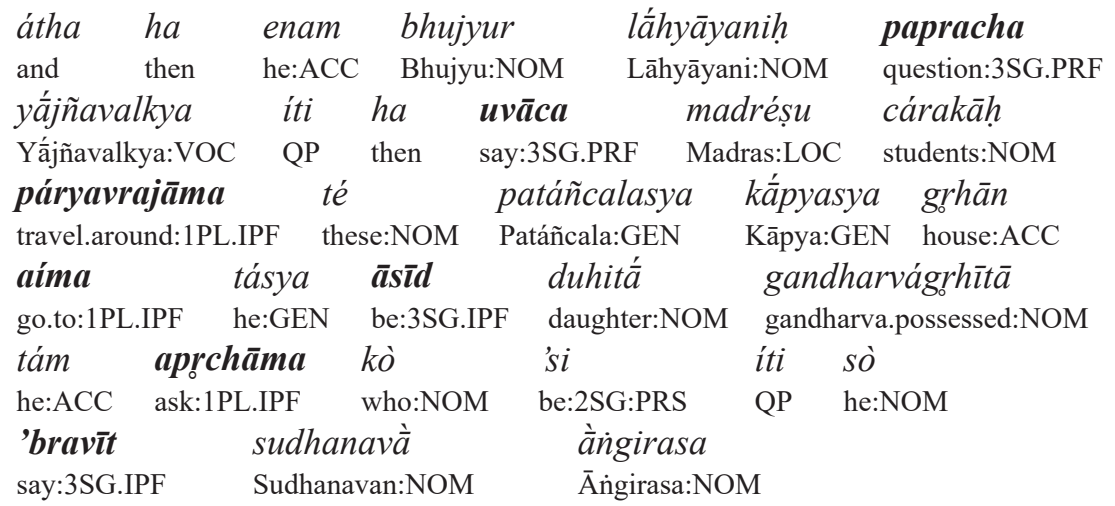

"Then Bhujyu Lāhyāyani began to question him. "Yājñavalkya" he said, "once, when we traveled around in the land of the Madras as itinerant students, we visited the home of Patañcala Kāpya. He had a daughter possessed by a Gandharva. We asked him who he was and, and the Gandharva said that he was Sudhanavan Āngirasa' (ŚBM XIV 6.3.1 = BĀU III 3.1 after Olivelle 1996)

These examples illustrate that Late Vedic Perfect Indicative forms such as $u v \bar{a} c a$ 'said', paprācha 'asked' are characteristically used in the narrative frame story, that Aorist Indicative forms like akrata 'have made', atyávādīs 'have outspoken', are used with a subjectively proximate or immediate past meaning, and that Imperfect forms of the type páryavrajāma 'travelled around', aima 'went to', äsīd 'was', aprchāma 'asked' and abravīt 'said' are used in remote past contexts within the speaker's own experience. Evidence from the Late Middle Vedic prose texts to be discussed below suggests that there was no aspectual difference between the three past tense categories at that stage and it is therefore reasonable to assume that this was the case in the immediately following chronological stage Late Vedic as well. 


\section{Grounding TAM Semantics: Tense, Aspect and Mood as Relations in temporal and modal space}

This section contains a brief outline of the most important theoretical assumptions on which the present work is based. Assuming that it is uncontroversial that one of the universal functions of sentences consists of relating individuals and situations to times and worlds, the semantic domains of tense and aspect both may be taken to concern the relation between individuals, situations and times, whereas modality may be understood as concerning the relation between individuals, situations and possible worlds. Most language-specific tense systems presuppose a linear concept of time, as schematically illustrated in Figure 1, and in the following this is taken to be a constitutive and hence universal feature of natural language.

Figure 1: Time as a dense monodimensional directed path structure

To some readers, the notion of a possible world may seem mysterious and speculative. It may therefore give rise to some controversy. In this work, a possible world is simply understood as a set of mutually consistent propositions. Although one could in principle conceive of worlds where time is not organized in a linear manner, I shall disregard this possibility in the following discussion, presupposing that, at least as far as grammar is concerned, speakers typically conceive of possible worlds as parallel linear sequences of events. Accordingly, one may tentatively assume that linear time and possible worlds represent complementary dimensions constituting a semantic space in which situations occur. This model is schematically represented in Figure 2 (cf. also Chierchia \& McConnel-Ginet 2000: 262).

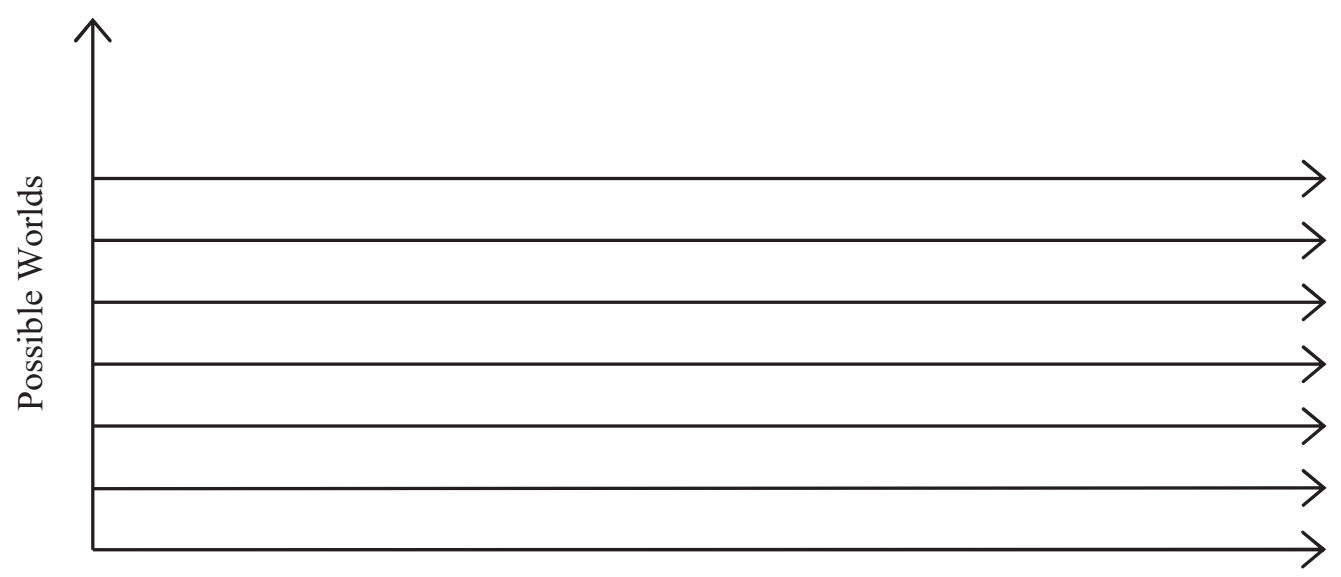

Time

Figure 2: Times and Possible Worlds as complementary dimensions in Semantic Space

I shall assume in the following that a model of this type constitutes the framework of temporal and modal interpretation in natural language. According to this approach, the basic 
function of temporal and modal markers is to specify the coordinates of situations in temporal and modal space. In Section 3.1 I define a set of notions which constitute a rudimentary framework for the analysis of tense and aspect semantics.

\subsection{Tense and Aspect - A neo-Reichenbachian approach}

Intuitively, tense distinctions involve implicit reference to two points or intervals in time, the time of the utterance or speech time and the time of the situation or event time. Under this assumption, the Early Vedic Imperfect, Aorist Indicative and Perfect Indicative, having past time reference, all express that the time of the situation is located prior to the time of the utterance, as illustrated, for instance, by the examples in (1) through (3) above. However, as first noted by the logician Hans Reichenbach (cf. Reichenbach 1947), two temporal parameters are insufficient to account for the difference in meaning between categories like the English Simple Past and Present Perfect in a principled manner. Both of these two types of categories are or at least can be used to express that a situation is located prior to the time of speech; however, while the Simple Past is perfectly compatible with adverbial expressions denoting a specific time in the past, the Present Perfect is generally incompatible with this kind of adverbials, as illustrated by the opposition between He visited me (yesterday) and He has visited me *(yesterday). In order to account for the semantic difference between the Simple Past and Present Perfect, Reichenbach introduced a third parameter, reference time. In his original system, the Simple Past denotes a relation such that event time coincides with reference time, both preceding speech time, while the Present Perfect denotes a relation such that event time precedes reference time which coincides with speech time. This assumption has a number of important corollaries. First, the above example suggests that reference time is the temporal parameter that may be made explicit by frame adverbs like yesterday, today or tomorrow and that such adverbs represent a heuristic cue to determine the temporal semantics of inflectional categories in corpus languages. In Section 2.2, I noted that the Early Vedic Perfect Indicative shows a number of readings also characteristic of the English Present Perfect. It is therefore tempting to assume that it represents a typologically very similar, if not identical category. This assumption finds some support in the fact that the Vedic Perfect Indicative generally does not occur with adverbial expressions denoting a specific past time, such as ágre 'in the beginning' and hyás 'yesterday' where we typically find the Imperfect or Aorist Indicative, as illustrated by the examples in (5).
a.

\begin{abstract}
indrāvaruṇā
\end{abstract}
yád rsșibhyo maniṣấm
Indra.and.Varuna:VOC when
sages:DAT
wisdom:ACC
vācó
matím
śrutám
adattam
ágre /
speech:ACC determination:ACC knowledge:ACC
$\begin{array}{ll}\text { yắni } & \text { sthánnāny } \\ \text { which:ACC } & \text { regions:ACC }\end{array}$
asrjanta
bestow:2DU.PRS beginning:LOC
spread.out:3PL.IPF
dhì $r \bar{r}$
yajñám tanvānās

\section{tápas $\bar{a} \sim$}
wise:NOM.PL
sacrifice:ACC performing:NOM
austerity:INS to
abhy àpaśyam //
'O Indra and Varuna, by religious austerity I saw to which regions the sages spread out when you two bestowed wisdom, speech, determination and sacred knowledge upon them in the beginning' (RV VIII 59.6 after Dahl 2010: 187) 


$\begin{array}{lll}\text { b. } \quad \text { tvắm id⿳亠口冋 } & \text { hyó } & \text { náró } \\ \text { you:ACC at.this.time } & \text { yesterday } & \text { men:NOM } \\ \text { 'pūpyan } & \text { vajrin } & \text { bhúrnayah / } \\ \text { make.swell:3PL.AOR } & \text { mace.holder:VOC } & \text { active:NOM }\end{array}$

'The active men made you swell at this time yesterday, O mace:holder' (RV VIII 99.1 ab after Dahl 2010: 269)

Under these assumptions, tense may be defined as a relation between reference time and speech time. However, it remains unclear how Reichenbach's three parameters can account for the typologically widespread use of categories with present time reference in past contexts, the so-called historical present, cf. e.g. yesterday, he comes home and finds his wife in bed with another man. Under the assumption that present tense involves a coincidence between reference time and speech time and the frame adverb yesterday picks out a specific reference time located prior to speech time, the model outlined so far seems to run into a paradox here. On somewhat different grounds, scholars like Kamp \& Reyle (1993) and Eberle \& Kasper (1994) have suggested that relative tenses such as the Past Perfect presuppose a fourth parameter, which is commonly labelled evaluation time. Evaluation time is understood as the temporal perspective from which something is regarded as past, present or future. This parameter is usually anchored in speech time but may be shifted to other times. Consider the examples from Early Vedic given in (6).

\begin{tabular}{|c|c|}
\hline \multirow[t]{3}{*}{ a. } & $\begin{array}{llll}\text { yadá } \sim \text { id } & \text { ádevīr } & \text { ásahișta } & m \bar{a} y \bar{a} \\
\text { When indeed } & \text { godless:ACC } & \text { defeat:3SG.AOR } & \text { sorceries:ACC }\end{array}$ \\
\hline & 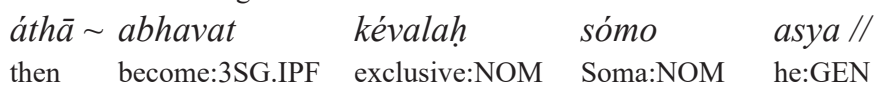 \\
\hline & $\begin{array}{l}\text { 'Indeed, when he had defeated (the) godless sorceries, then } \\
\text { his alone' (RV VII 98.5cd after Dahl 2010: 276) }\end{array}$ \\
\hline b. & $\begin{array}{lllll}\text { tváștā } & \text { yád } & \text { vájram̆ } & \text { súkrtam் } & \text { hiranyáyamँ } \\
\text { Tvaștar:NOM when } & \text { mace:ACC } & \text { well.made:ACC } & \text { golden:ACC } \\
\text { sahásrabhrștim̄ } & \text { svápā } & \text { ávartayat / } & \\
\text { thousand.pointed:ACC } & \text { skilful:NOM. } & \text { shape:3SG.IPF } & \end{array}$ \\
\hline
\end{tabular}

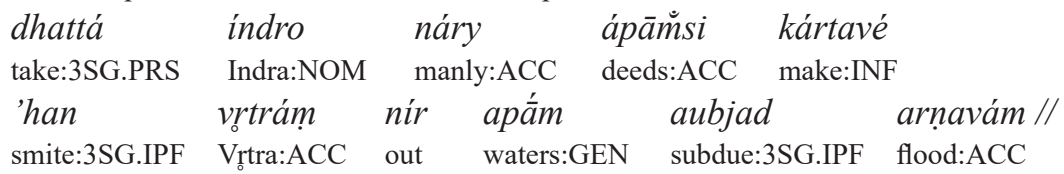

'When the skilful Tvaștar had shaped the well-made, golden, thousand-pointed mace, Indra took (it) for himself to perform manly deeds; He smote Vrtra, subdued the flood of the waters' (RV I 85.9)

In cases like these, Aorist Indicative forms like ásahișta 'defeated' and Imperfect forms like ávartayat 'shaped, was shaping' are used with a relative past value, i.e. to denote a situation which is located prior to another past situation. In the translation, this is indicated by the use of the Past Perfect. In the following, I shall assume that the main difference between the simple past reading illustrated in (5) and the relative past reading illustrated in (6) concerns the temporal anchoring of the evaluation time parameter, which in the first case is identified with speech time and in the second with the reference time of the main clause. From this perspective, the relative conjunctions yadá and yád 'when' may be regarded as 
a kind of operators shifting evaluation time from speech time to the reference time of the main clause (cf. also Dahl 2010: 176).

So far I have mainly focused on simple and complex tense relations and the notion of event time and its relation the other parameters has received little attention. Apart from the intuition that it represents a necessary part of temporal interpretation, its role in the system may appear somewhat less central than the other parameters. Indeed, its role in tense predication at most seems to be indirect, given that tense distinctions may be analyzed as different relations between reference time and evaluation time. Reichenbach's original system took points as the default value of the temporal parameters but this assumption appears to be somewhat too simplistic. For one thing, frame adverbs like yesterday, last year or for ten years intuitively refer to intervals rather than points in time and it is therefore reasonable to claim that a model based on intervals is more psychologically realistic. Here, I will adopt this hypothesis which has the immediate advantage that it provides a way of including aspectual distinctions in the Reichenbachian system.

The semantic distinction between the Present Perfect and the Simple Past noted above may be aspectual in nature but Reichenbach's original model is unable to capture the far more central aspectual distinction between imperfective and perfective aspect expressed by the Progressive Past construction of the type he was reading a book and the Simple Past construction of the type he read a book. Given that both of these constructions denote a precedence relation between reference time and evaluation time, the difference between them would appear to concern how they represent the relationship between reference time and event time. Indeed, the assumption that the temporal parameters take intervals as input suggests a straightforward way of representing the semantic difference between imperfective and perfective constructions. Specifically, in a sentence like he was reading a book yesterday the Progressive Past construction characteristically implies that the situation was left unfinished and predicates a relation between reference time and event time such that event time lasts longer than reference time. In contrast, in a sentence like he read a book yesterday the Simple Past construction typically suggests that the situation was finished within the interval picked out by the adverb, thus predicating a relation between reference time and event time such that reference time lasts longer than event time. This is schematically illustrated in Figure 3.

Figure 3 is intended to capture the following intuitions. First, sentences implicitly refer to four temporal parameters, speech time $\left(\mathrm{t}_{\mathrm{S}}\right)$ or the time of the utterance, event time $\left(\mathrm{t}_{\mathrm{E}}\right)$ or the run time of the event denoted by the predicate, reference time $\left(\mathrm{t}^{\prime}\right)$ or the time spoken about and evaluation time $\left(\mathrm{t}_{0}\right)$ or the temporal perspective of the speaker. Second, past tense predicates a precedence relation between reference time and evaluation time such that reference time precedes evaluation time, which in turn selects speech time as its default temporal anchor. Third, the aspectual difference between the Past Progressive and Simple Past amounts to different constellations between reference time and event time, the Past Progressive predicating a relation such that event time includes reference time and the Simple Past typically expressing that reference time includes event time.

The observant reader will have noted that I describe the aspectual specification of the Simple Past in slightly more vague terms than that of the Past Progressive. This choice reflects the intuition that the Past Progressive represents a semantically more specific aspectu- 

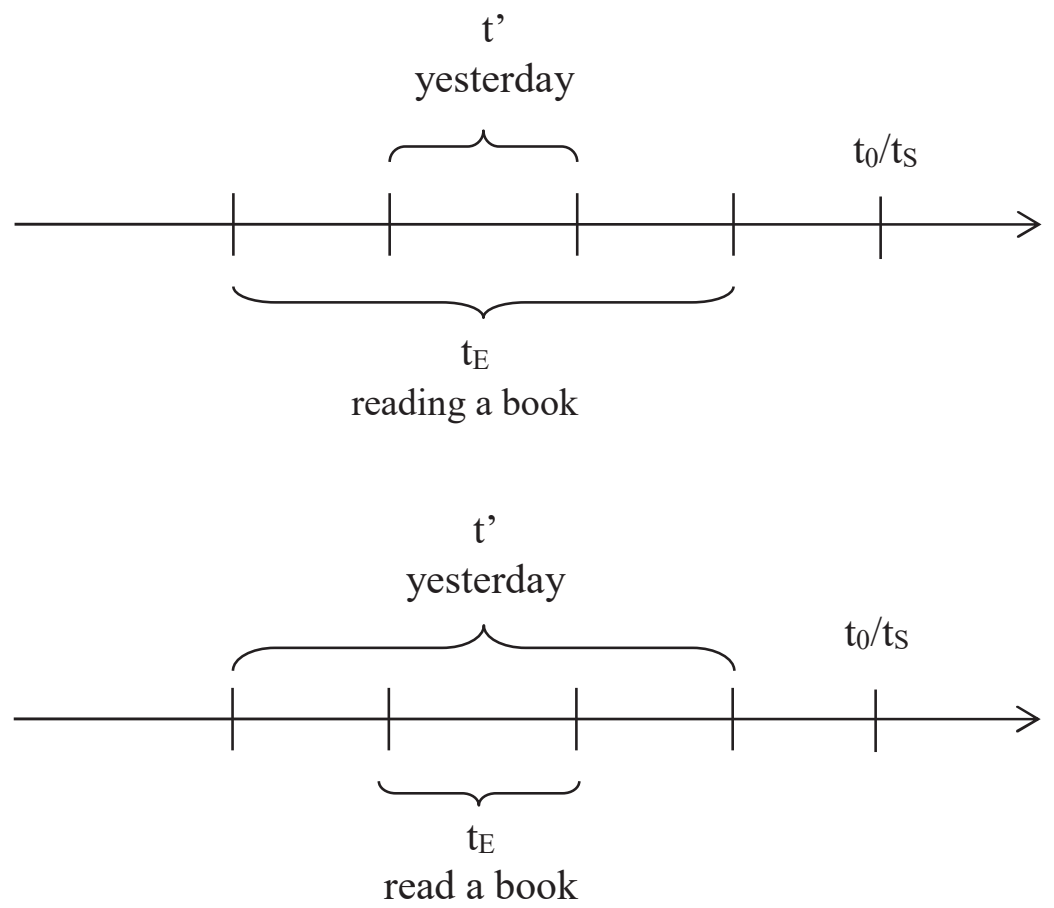

Figure 3: A time-relational analysis of the imperfective and perfective aspect

al category than the Simple Past. In fact, a case could be made for the claim that the English simple forms and their progressive counterparts represent privative aspectual categories, the progressive forms representing the marked terms and the simple forms unmarked terms. One fairly well established property of imperfective categories is that they can express that a situation is ongoing when another situation occurs, for instance in subordinate clauses introduced by temporal while, cf. e.g. He was mugged while he was going home. Given this, it is significant that the Simple Past is also allowed in such cases, as illustrated by the authentic sentence Two muggers robbed a Tremont man at gunpoint early Thursday while he walked home from a bar. ${ }^{4}$ While I cannot pursue this observation any further at present, such data clearly show that the English Simple Past is compatible with imperfective readings in addition to the perfective reading noted previously, thus representing an underspecified aspectual category which I label neutral, as opposed to perfective or imperfective. In the following, I shall assume that the English past tense system instantiates a general, perhaps universal property of aspect systems, namely that they typically contain one semantically general category denoting the neutral aspect and one or more specific aspect categories. Under the assumption that that the basic values of the temporal parameters are intervals, a number of relations may hold between them, such as general precedence $(\mathrm{A}<\mathrm{B}$ reads 'A precedes $\mathrm{B}$ '), general inclusion $(\mathrm{A} \subseteq \mathrm{B}$ reads $\mathrm{A}$ is included in $\mathrm{B}$ ) and overlap ( $\mathrm{A} \subset \mathrm{B}$ reads 'A overlaps with $\mathrm{B}$ '), immediate precedence (A $>\mathrm{B}$ reads ' $\mathrm{A}$ immediately precedes $\mathrm{B}$ '),

${ }^{4}$ www.cleveland.com/metro/index.ssf/2015/08/tremont_man_robbed_at_gunpoint.html. (Accessed 2016.04.11.) 
proper inclusion ( $\mathrm{A} \subset \mathrm{B}$ reads ' $\mathrm{A}$ is properly included in $\mathrm{B}$ ) or partial precedence $(\mathrm{A} \leq \mathrm{B}$ reads 'A precedes or overlaps with B'). These relations makes it possible to differentiate a number of tense and aspect categories, as outlined in Table 3.

Table 3: The semantic specification of the major tense and aspect categories

\begin{tabular}{c|c|c|c|c|c|c|c}
\hline & \multicolumn{3}{|c|}{ Tense Categories } & \multicolumn{4}{c}{ Aspect Categories } \\
\hline Name & Present & Past & Future & Neutral & Imperfective & Perfective & Anterior \\
\hline $\begin{array}{c}\text { Semantic } \\
\text { specification }\end{array}$ & $\mathrm{t}_{0} \subseteq \mathrm{t}^{\prime}$ & $\mathrm{t}^{\prime}<\mathrm{t}_{0}$ & $\mathrm{t}_{0}<\mathrm{t}^{\prime}$ & $\mathrm{t}^{\prime} \otimes \mathrm{t}_{\mathrm{E}}$ & $\mathrm{t}^{\prime} \subseteq \mathrm{t}_{\mathrm{E}}$ & $\mathrm{t}_{\mathrm{E}} \subseteq \mathrm{t}^{\prime}$ & $\mathrm{t}_{\mathrm{E}} \leq \mathrm{t}^{\prime}$ \\
\hline
\end{tabular}

A final observation regarding Reichenbach's original model concerns his treatment of the Past Perfect, which is defined as a predication where event time precedes reference time which in turn precedes speech time. The notion of evaluation time renders this analysis obsolete, since the Past Perfect in the present system rather has an analysis under which it expresses that reference time is prior to evaluation time and evaluation time is prior to speech time. More generally, it is reasonable to assume that the number of successive predicated relations of the same type may not exceed two, so that relations such as past in the past in the past or future in the future in the future would be a priori excluded as the temporal reference associated with a grammaticalized tense category in natural language. This restriction is intuitively reasonable, since these and similar relations have an overly complex structure and future research will show whether it holds.

It was noted previously in this paper that the Aorist Indicative has a past perfective semantics, something which in the present framework amounts to saying that it is obligatorily associated with the entailment that reference time precedes evaluation time/speech time $\left(t^{\prime}<t_{0}\right)$ and with the entailment that event time is included in reference time $\left(t_{E} \subseteq t^{\prime}\right)$. It was noted above that the Early Vedic Aorist Indicative is associated with a number of readings characteristic of this category type, notably a past completive reading (2a), an immediate past reading (2b) and an inchoative-ingressive reading (2c), repeated here as (7a-c) for convenience. Examples of some further characteristic readings are given in (7d-e).

(7) a.

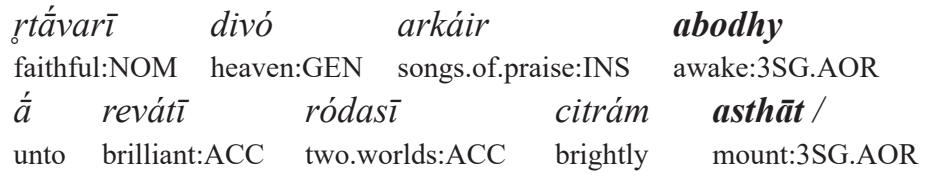

'The faithful (daughter) of heaven has awoken to (our) songs of praise. Brightly she has climbed unto the brilliant two worlds' (RV III 61.6ab after Dahl 2010: 272)

b.

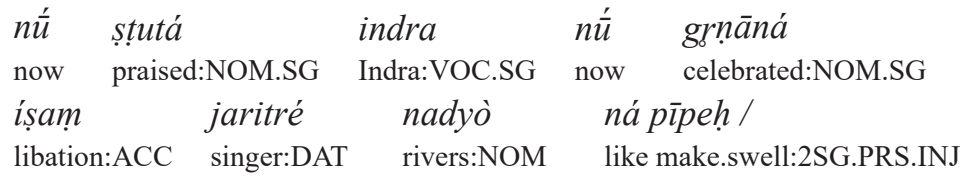

$\begin{array}{lllll}\boldsymbol{a} \boldsymbol{k} \boldsymbol{k} \boldsymbol{a} \boldsymbol{r} i & \text { te } & \text { harivo } & \text { bráhma } & \text { návyam } \\ \text { be.made:3SG.AOR } & \text { you:DAT } & \text { having.bay.horses:VOC } & \text { hymn:ACC } & \text { new:ACC }\end{array}$

'Now you have been praised, now you have been celebrated, you have made the libation swell for the singer like rivers. A new hymn has been made for you, o you whose horses are bay' (RV IV 16.21a-c after Dahl 2010: 265-266) 


$\begin{array}{lllll}\text { c. anyó } & \text { anyám } & \text { ánu } & \text { grbhn̄āty enor } \\ \text { another:NOM } & \text { another:ACC } & \text { after } & \text { take:3.SG.PRS the.two:GEN } \\ \text { apám } & \text { prasargé } & \text { yád } & \text { ámandișātām / } \\ \text { waters:GEN } & \text { outburst:LOC } & \text { when } & \text { be.delighted:3DU.AOR }\end{array}$

'One of the two grasps the other from behind, when they have become exhilarated in the discharge of the waters' (RV VII 103.4 after Jamison 1993: 140)

d. Súnaś cic chépam níditằ sahásrād even Śunahśepa:ACC bound:ACC thousand:ABL

$\begin{array}{llll}\text { yúpād } & \text { amuñco } & \text { áśamișta } & \text { hi șáh / } \\ \text { sacrificial.pole:ABL } & \text { release:2SG.IPF } & \text { be.prepared:3SG.AOR } & \text { for he:NOM }\end{array}$

'You even released Śunahśepa from [his] thousand [bonds], from the sacrificial pole, for he had exhausted himself (through sacrifice)' (RV V 2.7ab)

$\begin{array}{llll}\text { e. } & \text { divó } & \text { astoșy } & \text { ásurasya viráir } \\ \text { heaven:GEN } & \text { praise:1SG.AOR divine:GEN heroes:INS } \\ \text { ișudhyá } & \text { iva marúto } & \text { ródasyoh // } \\ \text { request:INS } & \text { like Maruts:ACC } & \text { worlds:LOC }\end{array}$

'With this request I praise the Maruts together with the heroes of the divine heaven in both worlds' (RV I 122.1cd)

One way to account for these various readings of the Early Vedic Aorist Indicative is to regard them as semantically specific variants of the past perfective meaning associated with this grammatical category. For example, given that a general inclusion relation may be interpreted as a proper inclusion relation or as a coextension relation, the perfective aspect may according to context give rise to at least two types of relations between event time and reference time. First, it may be interpreted as predicating a proper inclusion relation between these two parameters such that event time is properly included in reference time $\left(t_{\mathrm{E}}=\mathrm{t}^{\prime}\right)$. This reading may be assumed to underlie the sequential reading illustrated in (7a), the inchoativeingressive reading illustrated in $(7 \mathrm{c})$ and the relative past or 'flashback' reading illustrated in (7). On the other hand, the perfective aspect may be interpreted as a coextension relation between event time and reference time such that event time is coextensive with reference time $\left(\mathrm{t}_{\mathrm{E}}=\mathrm{t}^{\prime}\right)$. A time-relation of this kind appears to be presupposed by the occasional use of Aorist Indicative forms in performative-like contexts (7e) and in cases like the one cited in (7b), where the temporal scope of the Aorist Indicative form appears to comprise the hymn in which the verse occurs and of which it constitutes the last part. As regards temporal reference, I would above all draw attention to the fact that the Early Vedic Aorist Indicative is often used in immediate or proximate past contexts, as illustrated by the examples in (7a) and (7b), and, somewhat more rarely, in contexts with a less obviously immediate or proximate past time reference, as illustrated by the examples in (8).

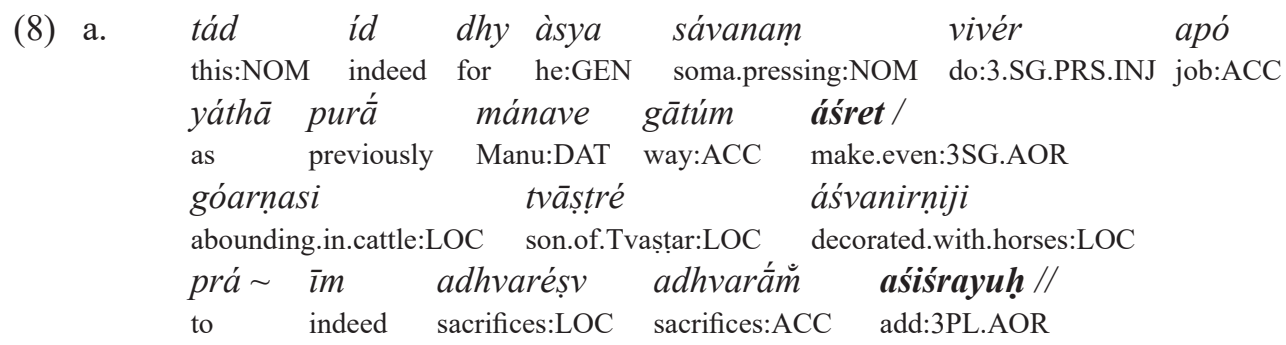


'For this libation has accomplished his work - as it previously made the way even for Manu - at (the place of) Tvașțar's son, who is abounding in cattle and decorated with horses. Indeed they have added sacrifices to sacrifices' (RV X 76.3)

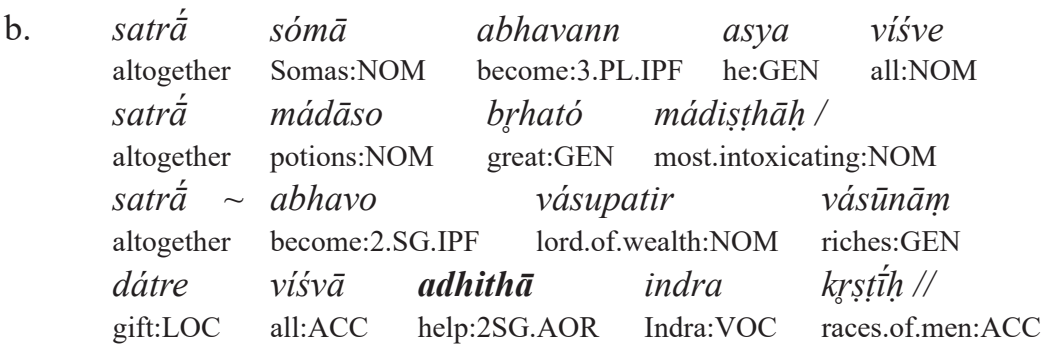

'All the somas became his altogether, the most intoxicating potions (belonged) to the great one. You became the wealth:lord of wealth, of the riches altogether. You helped all races of men to their gift' (RV IV 17.6)

Within the framework developed so far, the immediate past reading of the Aorist Indicative may be accounted for as a semantically specific variant of its general past time reference, predicating an immediate precedence relation between reference time and speech time/evaluation time such that reference time immediately precedes speech time/evaluation time $\left(t^{\prime}><t_{S} / t_{0}\right)$. Although the framework outlined in this section has a rather rudimentary character, I nevertheless hope to have shown that its relatively fine-grained set of distinctions enables a more detailed analysis of tense and aspect semantics than other, similar frameworks such as Klein (1995) or Kratzer (1998).

\subsection{Tense and Aspect categories as universal prototypes}

It was noted in Section 2 that cross-linguistic studies like Dahl (1985) and Smith (1997) have shown that semantically similar categories tend to have roughly the same set of lexically and contextually determined readings across languages. A case could therefore be made for the claim that Tense and Aspect categories like those defined in Table 3 represent universal prototypes which have predictable sets of readings. The various readings associated with a given Tense/Aspect category may be taken as semantically specific variants of a basic general meaning. The different readings associated with a given operator type may be understood as a structured set related by family resemblance, as schematically represented in Figure 4.

Figure 4 is intended to illustrate the idea that a given tense/aspect marker has a basic meaning (M) which combines with different types of verbal lexemes yielding slightly different derived meanings $\left(\mathrm{m}_{1}, \mathrm{~m}_{2}\right)$ which in turn are modified in different ways by contextual factors $\left(\mathrm{m}_{1}, \mathrm{~m}_{1}, \mathrm{~m}_{2}, \mathrm{~m}_{2}\right.$, etc.). The present framework does not preclude that two or more semantically distinct categories in some cases may have one or more readings in common but minimally presupposes that two typologically different categories differ with regard to the presence or absence of one reading. The readings that distinguish two or more categories may accordingly be classified as typologically relevant. For example, it was noted earlier that a present anterior category like the English Present Perfect or Early Vedic Perfect In- 


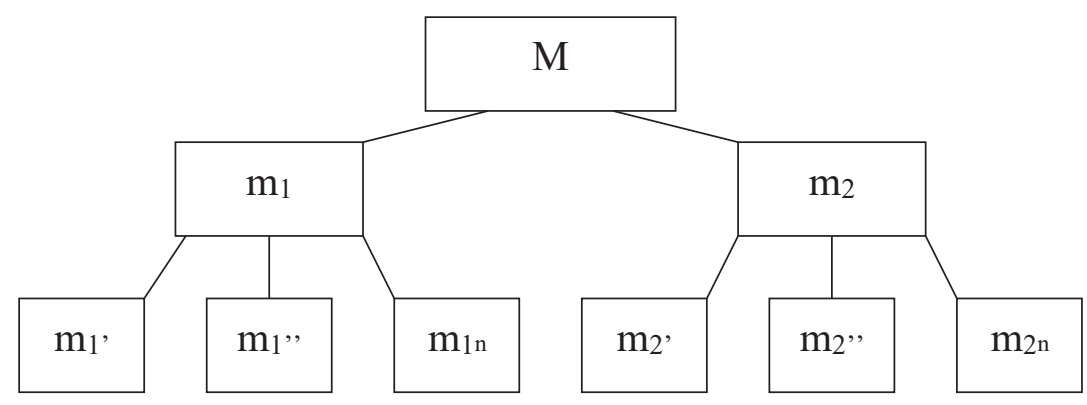

Figure 4: Lexically and contextually determined readings as networks of structured polysemy

dicative is compatible with a universal reading and incompatible with definite past reference times. In contrast, a simple past category with neutral aspectual semantics like the English Simple Past or the Early Vedic Imperfect is incompatible with a universal reading but perfectly compatible with definite past reference times. Accordingly, these two types of readings may be regarded as typologically relevant. From a methodological point of view, the presence of a given typologically relevant reading at one chronological stage and its absence at a later stage may be taken as prima facie evidence of typological change, a point which will be elaborated on in the following.

At this point it is reasonable to ask how the framework outlined here is equipped to deal with the various types of semantic change attested across languages. There is ample cross-linguistic evidence that the semantic specification of an inflectional category at one stage systematically restricts its possible diachronic outcome, given that a change occurs. One may broadly distinguish two different types of semantic change. One common type of semantic change consists in the conventionalization of pragmatic implicature. An element of meaning which at an early stage represents one context dependent reading in a cluster of readings associated with a given category may in the course of time become more closely associated with that category, gradually eliminating its other readings and eventually becoming part of its semantic specification (cf. Traugott \& Dasher 2005). An important question in this context concerns the role of the so-called typologically relevant readings in the process of change and whether they tend to be diachronically more stable than other, more peripheral readings.

Another pattern of semantic change may be called generalization of grammatical function, that is, the gradual erosion of a specific semantic feature, resulting in a more general category of a similar semantic type which is compatible with a broader range of contexts. Within the framework outlined in this work, this may be understood as the gradual acquisition of a growing number of context-dependent readings which at an early stage were associated with other morphosyntactic categories. Note that there is a certain tension between these two types of semantic change, as the first represents a development from a general to a more specific category, whereas the second represents a development from a specific to a more general category. Nevertheless it appears that both play an important role in the semantic evolution of verbal categories. 


\section{Aspects of semantic change in the Vedic past tense system}

In this section, I examine a number of stepwise semantic developments which contributed to the rather fundamental typological changes in the Vedic past tense system. The section is organized as follows. Section 4.1 deals with the development of the Aorist Indicative; the diachronic behavior of Perfect Indicative is the topic of Section 4.2, while that of the relatively stable Imperfect is discussed in Section 4.3.

\subsection{The development of the Vedic Aorist Indicative}

It was claimed previously in this paper with reference to Dahl (2010) that the Aorist Indicative was a past perfective category in Early Vedic. In the following I examine some important changes in its behavior which I believe are of particular importance for understanding the development pattern it instantiates, from a general past perfective category to an immediate past category.

First, it was noted above that the Early Vedic Aorist Indicative was compatible with a relative past reading, as illustrated, for instance, by examples (6a) and (7d), repeated here as (9a) and (9b) for convenience.

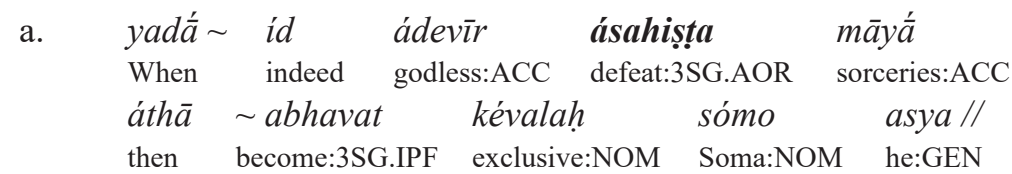

'Indeed, when he had defeated (the) godless sorceries, then the soma became his alone' (RV VII 98.5cd after Dahl 2010: 276)

b. Śúnaś cic chépam níditam̃ sahásrād

even Śunahśepa:ACC bound:ACC thousand:ABL

yúpād amuñco áśamișta hí șáh /

sacrificial.pole:ABL release:2SG.IPF be.prepared:3SG.AOR for he:NOM

'You even released Śunahśepa from [his] thousand [bonds], from the sacrificial pole, for he had exhausted himself (through sacrifice)' (RV V 2.7ab)

It was suggested above that the relative past reading of the Aorist Indicative may be understood as a contextually determined shift of the evaluation time parameter from its default value, speech time, to the reference time of the main clause. This kind of shift was taken to be typically caused by some operator like the relative conjunction yad ́̀ 'when' as in (9a) but also by inversion or a flashback in the discourse, as in (9b). Various scholars have noted that the Aorist Indicative represents the main expression of relative past in Early Vedic (cf. e.g. Kiparsky 1998 with references) and it is therefore reasonable to assume that the synchronic association between this category and this particular reading was quite strong. It is therefore all the more surprising that there are extremely few examples of Aorist Indicative forms with a relative past reading in the following stages of Vedic. Already in Early Middle Vedic, the Imperfect is regularly used in relative clauses when the main clause has past time reference, as illustrated by example (10a). The Aorist Indicative only occurs in relative clauses when the main clause has present time reference, as illustrated by example (10b). However, I have found a couple of instances where Aorist Indicative forms seem to be used in flashbacks with a relative past meaning, as illustrated in (10c). 


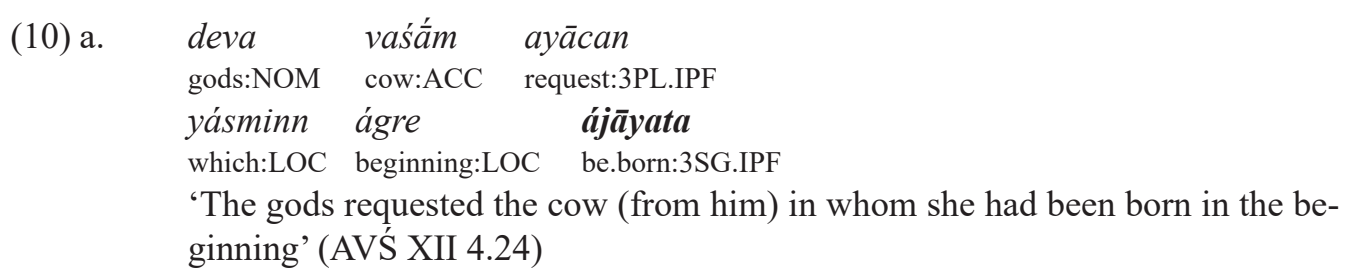

b. yád áśravan paśáva udyámānam

which hear:3PL.AOR cattle:NOM be.said:PRS.PRT

$\begin{array}{llll}\text { tád } & \text { bráhmaṇ } & \text { púnar asmán upáitu } \\ \text { that:NOM } & \text { mantra.spell:NOM again } & \text { we:ACC approach:3SG.PRS.IMP }\end{array}$

'The mantra spell which the cattle heard being said shall approach us again' (AVŚ VII 66.1)

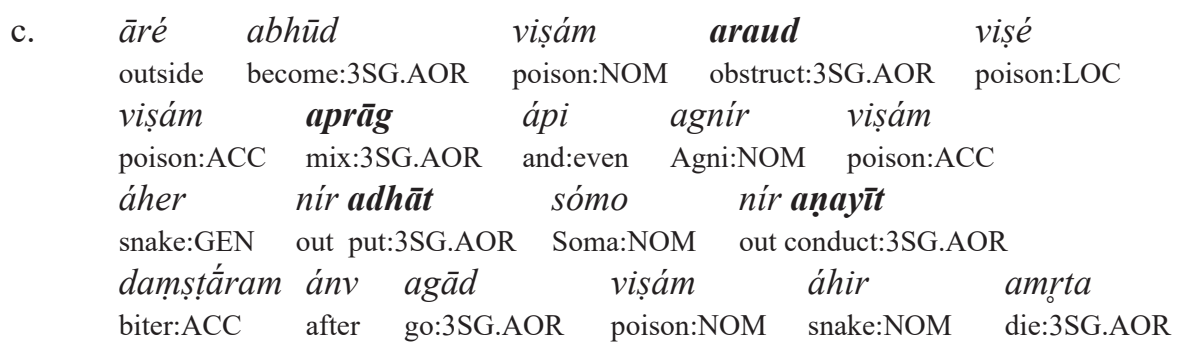

'The poison has come out. He obstructed the poison and mixed it in poison. Agni put out the poison of the snake. Soma conducted it out. The poison has gone after the biter. The snake has died' (AVŚ X 4.26)

One way of interpreting these data is that the Aorist Indicative was about to lose or had lost its immediate past reading in Early Middle Vedic and had become more strongly associated with the implicature that evaluation time coincides with speech time $\left(t_{0}=t_{S}\right)$. In other words, the Early Middle Vedic Aorist Indicative appears to be well on its way to develop into an absolute tense, i.e. a category incompatible with a relative temporal interpretation. This assumption is corroborated by the fact that no examples of Aorist Indicative forms in relative past contexts are found in later stages of Vedic.

Attention should also be drawn to the fact that Aorist Indicative forms in contexts explicitly or implicitly referring to a non-immediate or remote past time are almost non-existent after the Early Vedic period. The examples in (11a) and (11b) illustrate that they are still occasionally found in Early Middle Vedic and Middle Vedic.
(11) a.
devó $\quad$ deváir
heavenly:NOM gods:INS
mádhuśākhah
having.sweet.branches:NOM
vánaspátir
híranyaparno
lord.of.plants:NOM gold.leafed:NOM
supippaló devám
$\begin{array}{llll}\text { indram } & \text { avardhayat. } & \text { Dívam ámana asprkșad } \\ \text { Indra:ACC } & \text { strenghten:3SG.IPF } & \text { heaven:ACC } & \text { top:INS touch:3SG.AOR }\end{array}$
$\begin{array}{llll}\dot{a} & \text { antáriksạ̣ } & \text { prthivìm } & \text { adromhīd } \\ \text { towards } & \text { atmosphere:ACC } & \text { earth:ACC } & \text { make.firm:3SG.AOR }\end{array}$
'The heavenly lord of the plants (Soma) whose leaves are golden, whose branches and berries are sweet strengthened the god Indra. He touched heaven at the top, he made the atmosphere and earth firm' (VSM XXVIII $20=$ VSK XXX 1.20) 


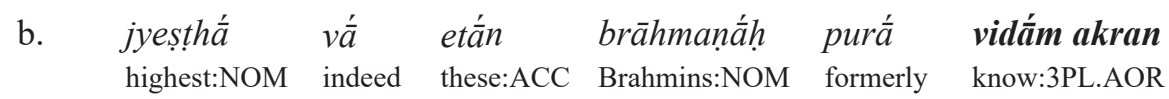

tásmāt téșāim sárvā diśo 'bhíjitāa abhūvan

therefore they:GEN all:NOM quarters:NOM conquered:NOM become:3PL.AOR 'Indeed, the highest Brahmins formerly knew them (the Prāṇa-cups). Therefore all quarters were conquered by them' (TS ${ }^{\mathrm{P}}$ III 5.10.2)

On the other hand, Aorist Indicative forms are frequently met with in contexts with an immediate or recent past time reference, as illustrated from the Early Middle Vedic example in (12a), the Middle Vedic example in (12b), the Late Middle Vedic example in (12c) and the Late Vedic example in (12d).

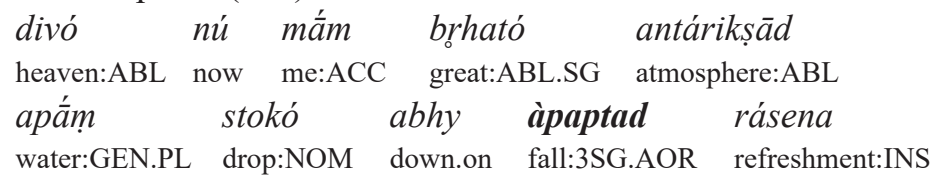

'Just now a drop of water has fallen down on me with refreshment from heaven, from the great atmosphere' (AVŚ VI 124.1)

b. yamó vó amriyata té deváa yamyá

Yama.NOM indeed die:3SG.IPF these:NOM gods:NOM Yamī:ABL

yamám ápābruvam̆s. tấm yád áprchant sá

Yama:ACC dissuade:3PL.IPF she:ACC when ask:3PL.IPF she:NOM

abravīd adyá amrta iti. tè 'bruvan

say:3SG.IPF today die:3SG.AOR QP they:NOM say:3PL.IPF

ná váa iyám imam itthám mrșyate

not indeed she:NOM he:ACC in.this.manner forget:3SG.PRS

rátrīm srjāvahā ity áhar vầvá tárhy ásīn

night:ACC create:1PL.SBJ QP day:NOM just at.that.time be:3SG.IPF

ná rấtris. té devấ rắtrim asrjanta

not night:NOM these:NOM gods:NOM night:ACC create:3SG.IPF

tátah śvástanam abhavat tátạ̣ sá

then tomorrow:NOM become:3SG.IPF then she:NOM he:ACC forget:3SG.IPF

'Yama died. The gods dissuaded Yamī from Yama. When they had asked her, she said: "He has died today." They said: "In this way will she not forget him. Let us create the night." At that time the day existed, but the night did not. The gods made the night. Afterwards it became morning. Then she forgot him' $\left(\mathrm{MS}^{\mathrm{P}}\right.$ I 5.12)

c. tam ha jāyaya abhijagrāha śacyā paulomyā

he:ACC then wife:INS catch:3SG.PRF Śacī:INS Paulomī:INS

tām ha uvāca kathā ìtyam akar iti

she:ACC then say:3SG.PRF why harm:ACC do:2SG:AOR QP

sāa ha uvāca na vām vyajñāsam iti

she:NOM then say:3SG.PRF not you.two:ACC distinguish:1SG.AOR QP

'He (Indra) caught him (Kutsa Aurava) in the act with his own wife Śacī Paulomī. He said to her "Why did you do this harm (to me)?" She said: "I did not distinguish you from each other"' (JB III 199) 


\begin{tabular}{|c|}
\hline 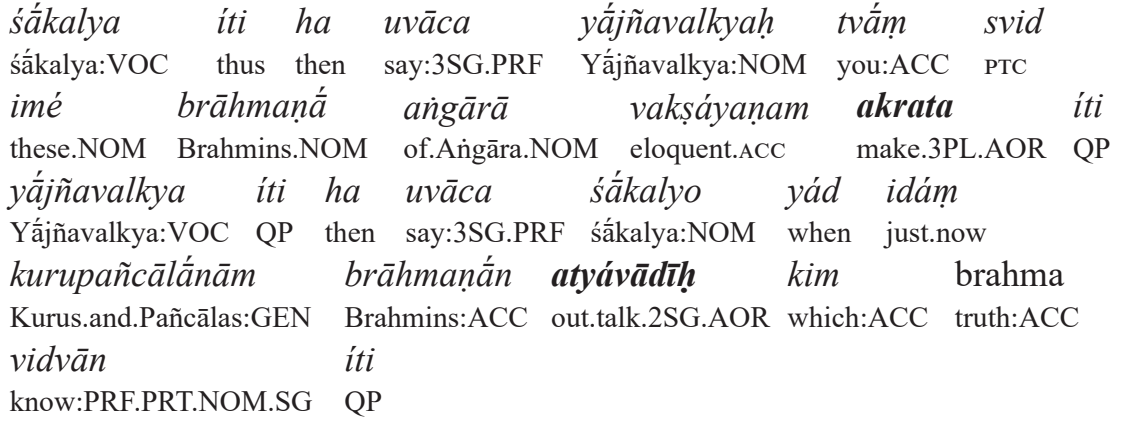 \\
\hline
\end{tabular}

'Yājñavalkya said: "Śākalya, it is clear that the Brahmins from Añāa have made you eloquent." Śākalya said: "Tell me, Yājñavalkya, which truth did you know when you out-talked the Brahmins of Kuru and Pañcāla just now?", (ŚBM XIV 6.9.19-20 = BĀU III 9.19)

The data briefly reviewed here may be taken to suggest that the recent past reading of the Early Vedic Aorist Indicative represents one among other contextually determined temporal readings which in the course of time it gradually becomes more strongly entrenched, so that the Aorist eventually loses its other temporal readings. Judging from the data, the first reading to disappear is the relative past reading which is completely obsolete already in Early Middle Vedic. From that time on, the Aorist Indicative may be assumed to have acquired the entailment that evaluation time coincides with speech time $\left(\mathrm{t}_{0}=\mathrm{t}_{\mathrm{S}}\right)$. The second step in this process is that the use of the Aorist Indicative in context with a non-immediate past time reference gradually disappears, being rare in Early Middle Vedic and Middle Vedic and completely obsolete by the Late Middle Vedic period. Within the framework outlined previously in this paper, the fact that the Late Middle Vedic and Late Vedic Aorist Indicative was exclusively associated with the immediate past reading entails that it was obligatorily expressing that reference time immediately precedes evaluation time and that evaluation time coincides with speech time $\left(\mathrm{t}^{\prime}><\mathrm{t}_{0}, \mathrm{t}_{0}=\mathrm{t}_{\mathrm{S}}\right)$, unlike the Early Vedic Aorist Indicative which had a richer set of temporal readings.

As regards aspectual reference, on the other hand, the Aorist Indicative generally appears to be somewhat more conservative. For instance, the Early Middle Vedic Aorist Indicative seems to represent a past perfective category just like its Early Vedic predecessor. This may be illustrated by the examples in (13), where Early Middle Vedic Aorist Indicative forms are used with a sequential reading (13a), an inchoative-ingressive reading (13b) and a performativelike reading (13c). Earlier in this paper, these three readings were taken to represent two different realizations of the perfective aspect, the sequential reading and the inchoative-ingressive reading presupposing that event time is properly included in reference time $\left(t_{E} \subset t^{\prime}\right)$ and the performative reading presupposing that event time is coextensive with reference time $\left(t_{E}=t^{\prime}\right)$.
(13) a.
apó
divyá
acāyișam
waters:ACC heavenly:ACC.PL be.reverent:1SG.AOR
$\begin{array}{lll}\text { rásena } & \text { sám } & \text { aprkșmahi } \\ \text { fluid.refreshment:INS } & \text { together } & \text { mix:1PL.AOR }\end{array}$
páyasvān agna ágamạ̣
endowed.with.water:NOM.SG Agni:VOC come.hither:1SG.AOR

'I have been reverent to the heavenly waters, I have mixed with the fluid refreshment. O Agni, endowed with water I have come hither' (AVŚ VII 89.1) 


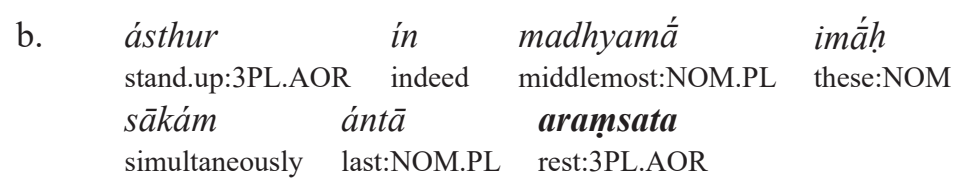

'The middlemost have stood up and simultaneously the last ones have come to rest' (AVŚ I 17.3)

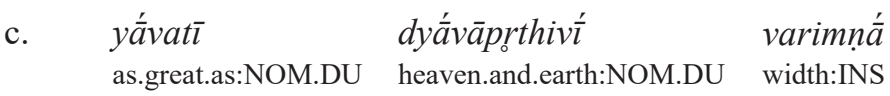

yắvat saptá síndhavo vitașthiré

as.much.as seven rivers:NOM spread.out:3.PL.PRF

vắcam vișásya dúṣaṇīn

spell:ACC poison:GEN destroying:ACC.SG

tám itó nír avādiṣam

this:ACC from.here out speak:1SG.AOR

'As great as heaven and earth are by their width, as much as the seven rivers have spread out, I speak out from here this poison-destroying spell' (AVŚ IV 6.2)

Again, the fact that there appear to be no unambiguous examples of Early Middle Vedic Aorist Indicative forms being used with a meaning incompatible with the perfective aspect corroborates the assumption that it denotes the perfective aspect. In Middle Vedic proper, the Aorist Indicative has roughly the same set of contextually determined readings but note that it does not seem to be used in performative sentences at this stage.

In Late Middle Vedic, Aorist Indicative forms also seem to show an inchoative-ingressive and a completive-sequential reading, as illustrated by the examples in (14).

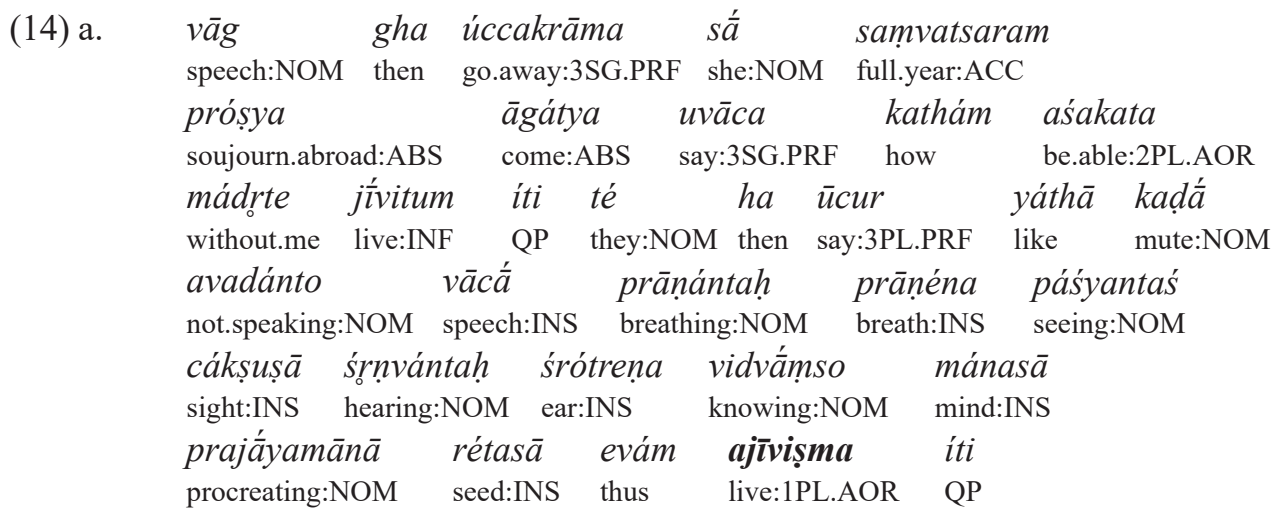

'Then Speech went away. After having sojourned abroad for a full year and come (back) she said: "How have you been able to live without me?" They said: "Like mutes unable to speak with speech, breathing with breath, seeing with the eye, hearing with the ear, knowing with the mind and procreating with seed, like this we (suddenly) lived"' (ŚBM XIV 9.2.8)

b. indram vai bhūtāni paryacakșata triśsirșāṇam

Indra:ACC indeed beings:NOM condemn:3PL.IPF three.headed:ACC

tvāṣtram avadhīd yatīn sālāvrkebhyah prādād

Tvāṣtar:ACC smite:3SG.AOR Yatis:ACC jackals:DAT give:3SG.AOR 


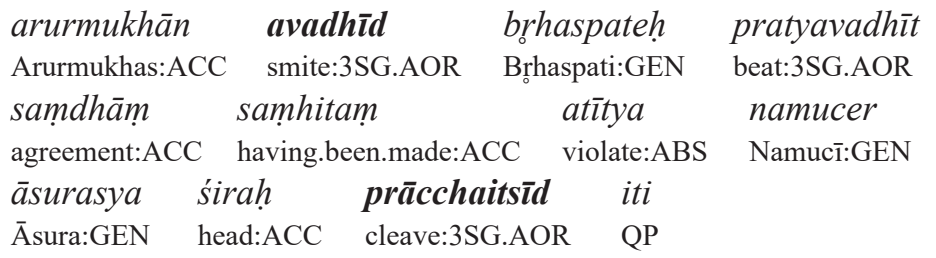

'The beings condemned Indra: "He has killed Tvāșțar with three heads, he has given the Yatis to the jackals, he has killed the Arurmukhas, he has hit at Brhaspati. An agreement being made, he cut off the head of the Āsura Namucī, being his guest"' (JB II 134)

Significantly, however, the Late Middle Vedic Aorist Indicative is occasionally used with a markedly imperfective meaning. Consider, for instance, the example cited in (15).

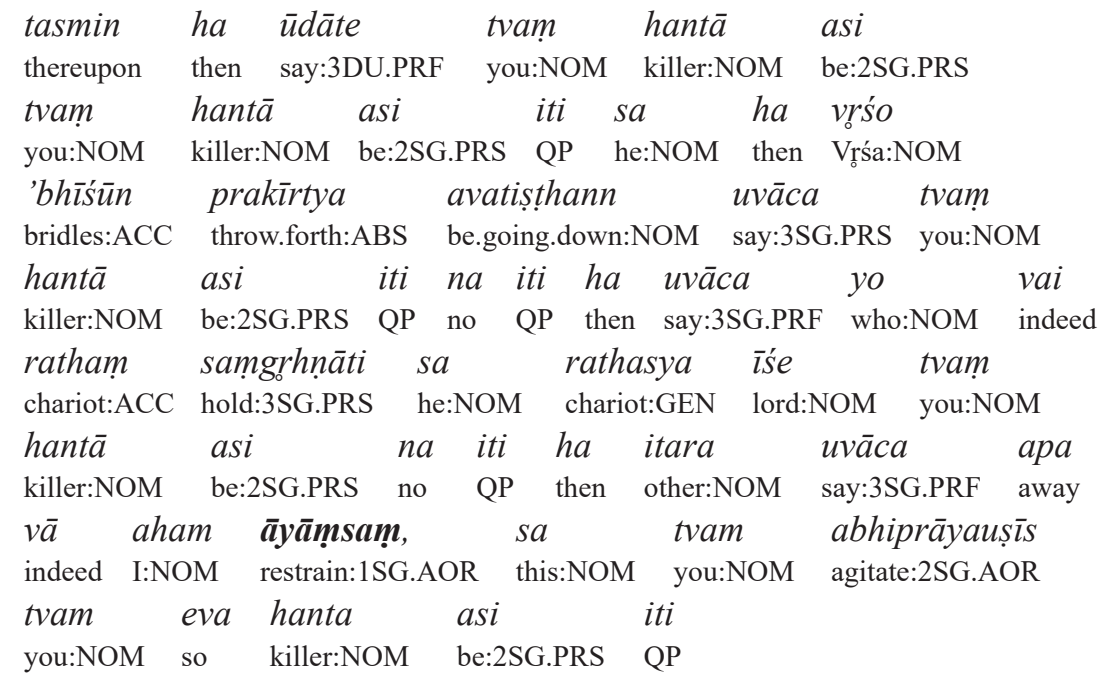

'Then they started arguing: "You are the killer, you are the killer. Having laid down the two bridles, Vrśa said while stepping down: "You are the killer". "No," he said, "he who has hold on the wagon, he is the lord of the wagon. You are the killer." "No," said the other, "I was stopping, but you were agitating. Thus you are the killer."' (JB III 94)

The aspectual relation underlying the reading illustrated in (15), which may be labeled 'conative-preliminary', is fundamentally incompatible with the perfective aspect. Specifically, a markedly imperfective reading of this kind would seem to presuppose that reference time were properly included in event time $\left(\mathrm{t}^{\prime} \subset \mathrm{t}_{\mathrm{E}}\right)$, an aspectual relation which cannot be derived from that denoted by the perfective aspect $\left(t_{\mathrm{E}} \subseteq \mathrm{t}^{\prime}\right)$. This is a clear indication that the Aorist Indicative did not represent a perfective category in Late Vedic, something which suggests that it has undergone a significant semantic change. It was noted earlier that the Early Vedic Imperfect was compatible with perfective-like as well as imperfective-like readings and this was taken as evidence for its neutral aspectual character, something which under the assumptions outlined earlier in this paper amounts to saying that it denotes a general overlap relation between event time and reference time $\left(t^{\prime} \otimes t_{E}\right)$. These considerations 
suggest that the Late Vedic Aorist Indicative denoted the neutral aspect. However, this begs the question as to how the general inclusion relation denoted by the perfective aspect relates to the general overlap relation denoted by the neutral aspect and in particular how a perfective category can develop a neutral meaning.

The neutral aspect can give rise both to a sequential reading, as illustrated by example (1a) and to a temporally overlapping reading, as illustrated by example (1b), both repeated here for convenience.

\begin{tabular}{|c|c|c|c|}
\hline $\begin{array}{l}\text { sáudhanvanā } \\
\text { sons.of.Sudhanvan:VOC }\end{array}$ & $\begin{array}{l}\text { áśvād } \\
\text { horse:ABL }\end{array}$ & $\begin{array}{l}\text { áśvam } \\
\text { horse:ACC }\end{array}$ & $\begin{array}{l}\text { atakșata } \\
\text { shape:2.PL.IPF }\end{array}$ \\
\hline $\begin{array}{ll}\text { yuktváa } & \text { rátham } \\
\text { yoke:ABS } & \text { wagon:ACC }\end{array}$ & $\begin{array}{l}\text { úpa } \\
\text { to }\end{array}$ & $\begin{array}{l}\text { devám } \\
\text { gods:ACC }\end{array}$ & $\begin{array}{l}\text { ayātana // } \\
\text { drive:2.PL.IPF }\end{array}$ \\
\hline
\end{tabular}

'O sons of Sudhanvan, from a horse you created a (second) horse. Having yoked the wagon, you drove to the gods' (RV I 161.7cd after Dahl 2010: 192)

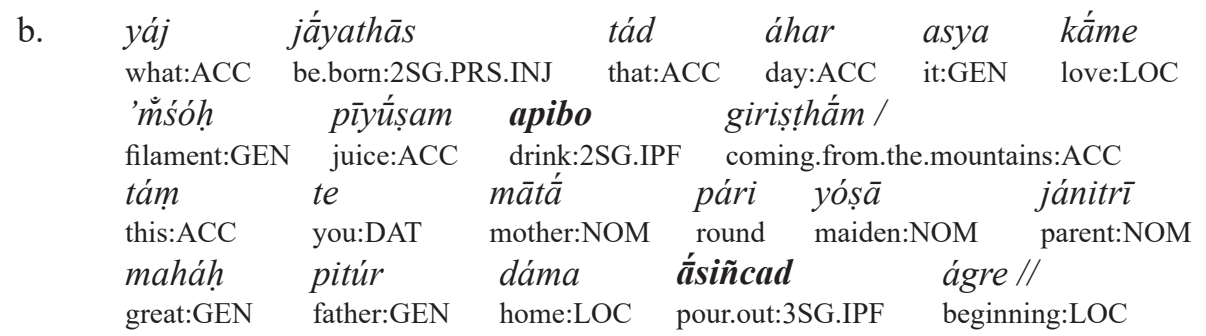

'On the day when you were born you voluptuously drank nectar of the plant which comes from the mountains. Your mother, the young maiden, was pouring it abundantly out for you in the house of your great father for the first time' (RV III 48.2 after Dahl 2010: 203-204)

Assuming that the sequential reading presupposes that event time is properly included in reference time $\left(\mathrm{t}_{\mathrm{E}} \subset \mathrm{t}^{\prime}\right)$ and that the overlapping reading presupposes that reference time is properly included in event time $\left(\mathrm{t}^{\prime} \subset \mathrm{t}_{\mathrm{E}}\right)$, both of these aspectual relations may be regarded as contextually determined variants of the general overlap relation denoted by the neutral aspect. As the perfective aspect is taken to express a more general inclusion relation than the specific sequential reading, it is reasonable to conclude that the perfective aspect may be interpreted as a specific category which is compatible with a proper subset of the readings with which the neutral aspect is compatible. In other words, from one perspective, the perfective aspect may be regarded as a semantically specific subtype of the neutral aspect. Consequently, the aspectual dimension in the development of the Aorist Indicative from Early Vedic to Late Vedic seems to represent a paradigm case of generalization of grammatical function, where a semantically specific category develops into a semantically more general category. Thus, the Vedic Aorist Indicative shows two distinct development patterns through its attested history. The first concerns its temporal reference which changes from a general past time reference to an absolute immediate past time reference, involving the conventionalization and strengthening of pragmatic implicature. The second concerns its aspectual reference which changes from perfective to neutral, and involves generalization of grammatical function. As regards the relative chronology of these two development patterns, it is likely that the first predates the second, as a more specific temporal semantics might be 
expected to give rise to a more general aspectual semantics, given that a fully developed immediate past category would have to be able to be used in any type of discourse context with the appropriate temporal reference. This assumption finds some support in the fact that the immediate past reading of the Aorist Indicative seems to have been generalized in the Middle Vedic period, while the first clear indication that it has a neutral aspectual character is found in Late Middle Vedic.

\subsection{The development of the Vedic Perfect Indicative}

It was noted above that the Early Vedic Perfect Indicative denotes the anterior aspect, that is, it is taken to represent a category with essentially the same semantic properties as the English Present Perfect (cf. also Dahl 2010 chapter five). Within the present framework, the anterior aspect is defined as a partial precedence relation between event time and reference time such that event time precedes or overlaps with reference time. We have already seen that the Early Vedic Perfect Indicative is associated with an existential, a universal and a resultative reading, illustrated by the examples cited in (3), repeated here as (16a-c) for convenience. In addition, the Early Vedic Perfect Indicative has a present state reading with certain verbs, as illustrated by example (16d), and in some cases seems to have an inferential reading, as illustrated by example (16e).

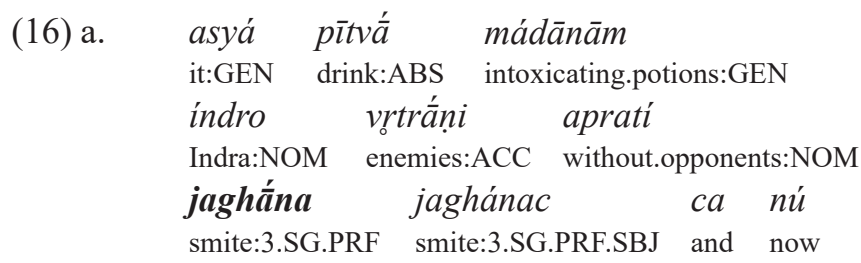

'Having drunk of its intoxicating potions Indra who is without opponents has smitten enemies and will also now smite enemies' (RV IX 23.7)

b. śáśsad dhi vah sudānava ádityā

continuously for you:GEN munificent:VOC.PL Ādityas:VOC

ūtíbhir vayám purá nūnám bubhujmáhe

favours:INST we:NOM previously now enjoy:1.PL.PRF.MID

'For we have continuously been enjoying ourselves with your favors, o munificent Ādityas, formerly (and) now' (RV VIII 67.16)

$\begin{array}{llll}\text { c. } & \quad \text { ádhvaryo } & \text { drā váya } & \text { tvám } \\ & \text { Adhvaryu:VOC } & \text { make.flow:2SG.PRS.IMP } & \text { you:NOM }\end{array}$

sómam indrah pipāsatil

soma:ACC Indra:NOM be.thirsty:3SG.PRS

úpa nūnám yuyuje vŕș̣aṇā

unto now yoke:3SG.PRF horses:ACC

hárī à ca jagāma vrtrahá //

bay:ACC to and come:3SG.PRF Vrtrakiller:NOM

'Adhvaryu, you let the soma flow! Indra is thirsty. Now the Vrtrakiller has yoked his two bay horses and has come hither' (RV VIII 4.11)

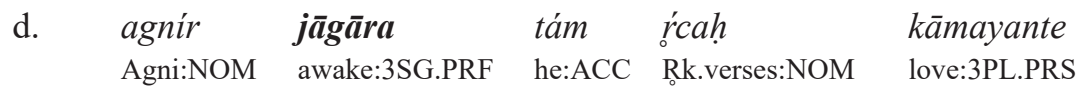




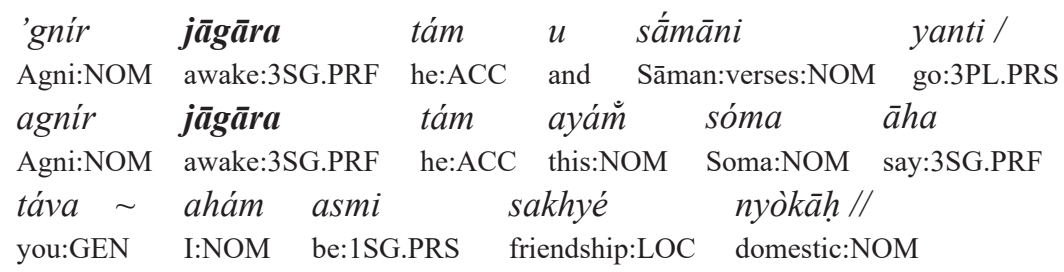

'Agni is wakeful, him the Rok-verses love. Agni is wakeful, and to him the Sāman-verses go. Agni is wakeful, to him this Soma says: "In your friendship I feel at home"' (RV V 44.15 after Dahl 2010: 358)
e.

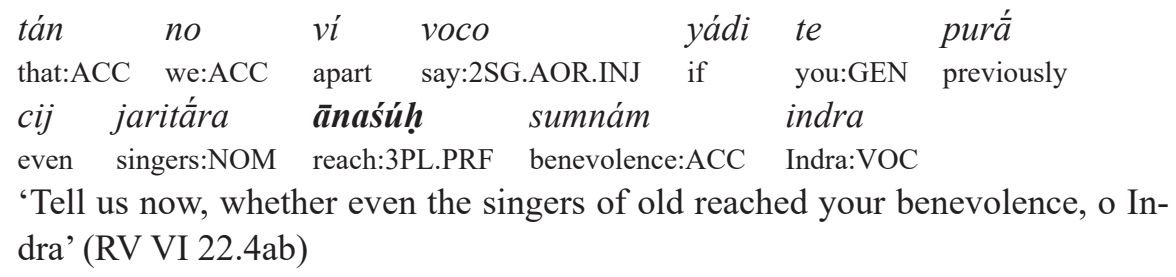

Dahl (2010) argues that the universal reading of the Perfect Indicative presupposes a coextension relation between event time and reference time $\left(t_{\mathrm{E}}=\mathrm{t}^{\prime}\right)$, while the other readings rather appear to predicate a precedence relation between these two parameters, such that event time precedes reference time $\left(\mathrm{t}_{\mathrm{E}}<\mathrm{t}^{\prime}\right)$. The existential reading is vague with regard to how many instances of the situation have occurred prior to reference time. In contrast, the resultative reading characteristically involves reference to a single, specific situation. Under the present state reading, illustrated in (16d), the event proper is left out of focus. Finally, the inferential reading, illustrated in (16e) is taken to involve the indirect inference of a situation of the type named by the verb, a reading which is most obviously seen in indirect questions. As regards temporal reference, the Early Vedic Perfect Indicative may be characterized as a 'retrospective' present tense rather than a past tense strictly speaking, in the sense that it presupposes that a part of the reference time interval is located prior to and properly includes evaluation time/speech time and does not extend beyond the latter. In other words, retrospective present tense denotes a proper inclusion relation between reference time and evaluation time/speech time such that reference time properly includes evaluation time/ speech time which is coextensive with the final subinterval of the reference time interval.

In Early Middle Vedic we note a number of changes in the behavior of the Perfect Indicative. One important innovation concerns the occasional occurrences of Perfect forms with adverbs denoting a definite past time, such as hyás 'yesterday' or ágre 'in the beginning', illustrated in (17).

$\begin{array}{llllll}\text { adyáa } & \text { mamáára } & \text { sá } & \text { hyáh } & \text { sám } & \overline{\boldsymbol{a}} \boldsymbol{n} \boldsymbol{a} / / \\ \text { today } & \text { die:3SG.PRF } & \text { he:NOM } & \text { yesterday } & \text { together } & \text { breathe:3.SG.PRF }\end{array}$

'Today (the moon) has died. Yesterday he was still fully breathing' (AVŚ IX $10.9 \mathrm{~d}=\mathrm{RV}$ X 55.5d $)^{5}$

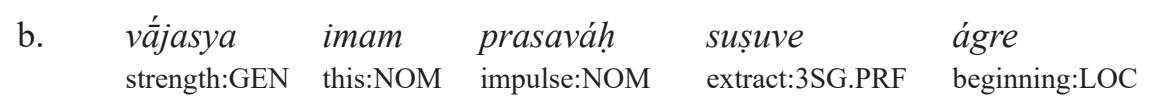

5 This is an instance where the Rigvedic hymn appears to be rather young and therefore may be regarded as belonging to Early Middle Vedic rather than Early Vedic. 


\section{sómaì rájānam óșadhīṣv apsú \\ soma:ACC king:ACC herbs:LOC waters:LOC \\ 'In the beginning, the impulse of strength extracted king soma from the herbs and waters' (TS $\left.{ }^{\mathrm{M}} \mathrm{I} 7.10 .1\right)$}

Examples like these clearly show that the Early Middle Vedic Perfect Indicative has a strictly past time reference. Under the assumptions introduced earlier in this paper, the change from retrospective present to simple past time reference would seem to involve a non-trivial transition from proper inclusion to precedence. However, assuming that the retrospective present presupposes that the evaluation time/speech time parameter is coextensive with the last interval of the reference time parameter, we only need to stipulate a rather straightforward reanalysis in order to account for this semantic change. Specifically, given that the notion of retrospective present denotes an indefinite interval prior to evaluation time/speech time which includes the latter as its final subinterval and the notion of past denotes an indefinite interval prior to evaluation time/speech time, one may easily imagine that speakers in certain types of discourse contexts reinterpret retrospective present as simple past by deleting the inference that evaluation time/speech time is coextensive with the last subinterval of the reference time interval. From one perspective, this development may be regarded as a change from a semantically rather specific tense category to a semantically more general tense category.

The assumption that the Early Middle Vedic Perfect Indicative has developed into a past tense is corroborated by the fact that there appear to be very few examples of Perfect Indicative forms with a universal reading. An example is given in (18a). What we do find, on the other hand, is a number of Present Indicative forms with a universal reading, i.e. expressing that a situation has been going on for some time and still holds at evaluation time/speech time, as illustrated by the example in (18b).

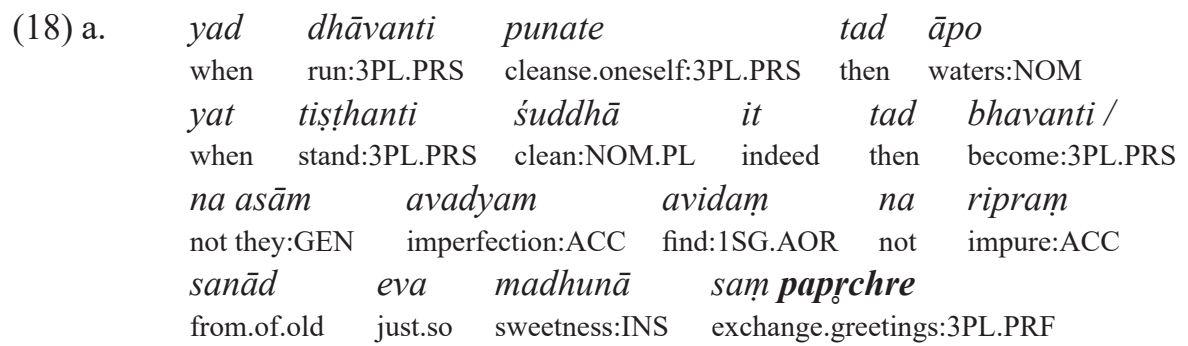

'When they stream, then the waters cleanse themselves; when they stand still, then they become pure. I have not found any imperfection or vice of theirs. From olden times they have exchanged greetings with the sweetness (Soma)' (AVP VI 3.10)

b.

$\begin{array}{llll}\text { sanád } & \text { agne } & \text { mrnasi } & \text { yātudhánā̄n } \\ \text { from.of.old } & \text { Agni:VOC } & \text { crush:2SG.PRS } & \text { evil.demons:ACC } \\ \text { ná tvā } & \text { rákșāmsi } & \text { pŕtanāsu } & \text { jigyuḥ/ } \\ \text { not you:ACC } & \text { Rakșas:NOM } & \text { battles:LOC } & \text { defeat:3PL.PRF }\end{array}$

'From olden times you have been killing evil demons. Not (once) have the Rakșas defeated you in battle"6 (AVŚ V 29.11ab)

${ }^{6}$ Cf. Whitney's translation (1905: 275): 'From of old, O Agni, thou killest the sorcerers; the demons have not conquered thee in fights.' The half-verse is also found in the Rigveda as RV X 87.19ab. 
As regards the aspectual properties of the Early Middle Vedic Perfect Indicative, we may note that it can be used to express that a single, specific situation of the type named by the verb has occurred once or more prior to evaluation time/speech time, as illustrated by examples (19a) and (19b). Occasionally, Perfect Indicative forms are used with a markedly imperfective reading, as illustrated by the example in (19c) where the form cakáara 'created' has an unmistakenly conative meaning.

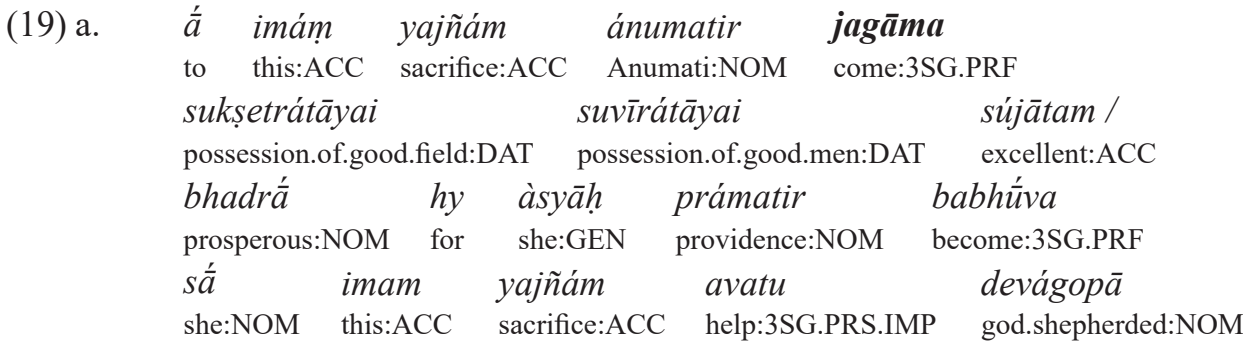

'Anumati has come unto this excellent sacrifice to grant us abundance of fields and heroes. For her providence has become prosperous (before). Let her, godshepherded, promote this offering'7 (AVŚ VII 20.5)

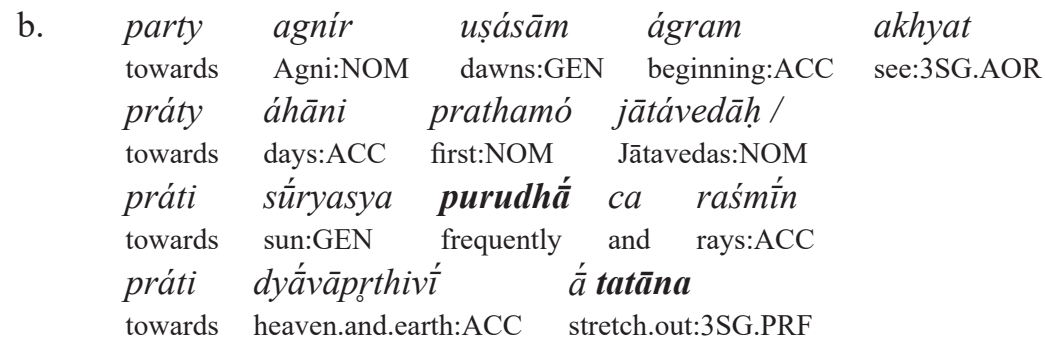

'Agni has seen the beginning of the dawns. Jātavedas is the first who (beholds) the days. He has frequently stretched towards the rays of the sun and towards heaven and earth" ${ }^{9}$ (AVŚ VII 82[87].5)

$\begin{array}{lccc}\text { c. } \quad \text { yáś } & \text { cakáára } & \text { ná śaśáka } & \text { kártum } \\ \text { who:NOM } & \text { create:3SG.PRF } & \text { not be.able:3SG.PRF } & \text { create:INF } \\ \text { śaśré } & \text { pádam } & \text { angúrim } & \\ \text { crush:3SG.PRF } & \text { foot:ACC } & \text { finger:ACC } & \\ \text { cakáára } & \text { bhadrám } & \text { asmábhyam } & \\ \text { create:3SG.PRF } & \text { good:ACC } & \text { we:DAT } & \end{array}$

ātmáne tápanam tú sáh

self:DAT painful:ACC but he:NOM

'He who created/tried to create, could not create, having crushed a foot (and) a finger. Nevertheless, he has created something auspicious for us but he is causing pain to himself"' (AVŚ IV 18.6)

${ }^{7}$ Cf. Whitney's translation (1905: 403): 'Anumati hath come unto this well-born offering, in order to [our] abounding in fields and in heroes; for her forethought hath been excellent; let her, god-shepherded, aid this offering.'

${ }^{8}$ Cf. Whitney's translation (1905: 449): 'Agni hath looked forth to meet the apex of the dawns, to meet the days, [he] first, Jātavedas, and to meet the rays of the sun in many places; to meet heaven and earth he stretched out.'

9 Cf. Whitney (1905: 182): 'He who hath made, hath not been able to make; he hath crushed a foot, a finger; he hath made what is excellent for us, but for himself a burning.' Bloomfield (1897: 70) translates the passage 
These considerations suggest that the Early Middle Vedic Perfect Indicative had a neutral aspectual value. Under the assumptions introduced earlier, this category may therefore be assumed to have undergone a semantic change from the anterior aspect to the neutral aspect, something which would involve a change from a partial precedence relation between event time and reference time to a general overlap relation between these two temporal parameters. Given that partial precedence as presently defined is understood as a complex, (inclusive) disjunction relation such that event time may precede or overlap (or both), the development into a general overlap relation may be understood as a development from a complex to a more simple and general aspectual category. More precisely, this change involves the loss of the implication that event time may precede reference time, something that most likely is a consequence of the development from retrospective present to general past time reference. Given the restriction that no more than two relations of the same nature may hold in the same predication suggested above, one might speculate that the loss of the mentioned implication was a consequence of the fact that the Perfect occasionally occurs with a shifted evaluation time already in Early Vedic. ${ }^{10}$

At this point it should be noted that I have not found any unambiguous examples where Perfect Indicative forms are used with a sequential reading in Early Middle Vedic. Given that the textual sources we have at our disposal from this period mainly contain mantras and magical spells and therefore present us with a very limited sample of the linguistic reality, this may be due to an accidental gap in the corpus. However, as will be addressed in somewhat more detail below, the Imperfect is regularly used as a sequential, narrative tense in Middle Vedic proper, the use of the Perfect Indicative in this type of context being rather restricted and seemingly never giving rise to a properly sequential reading. It is therefore all the more significant that Perfect Indicative forms are sporadically used among Imperfect forms in narrative contexts in certain Late Middle Vedic texts and having replaced the Imperfect as the main narrative tense in others. This may be illustrated by the examples in (20).

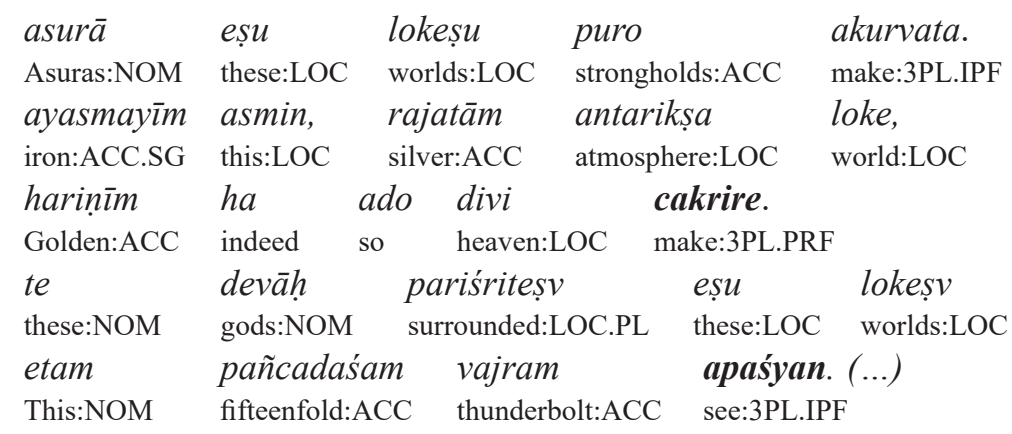

as follows: 'He that has undertaken them has not been able to accomplish them: he broke his foot, his toe. He performed a lucky act for us, but for himself an injury.'

${ }^{10} \mathrm{Cf}$. By way of illustration, the following example:

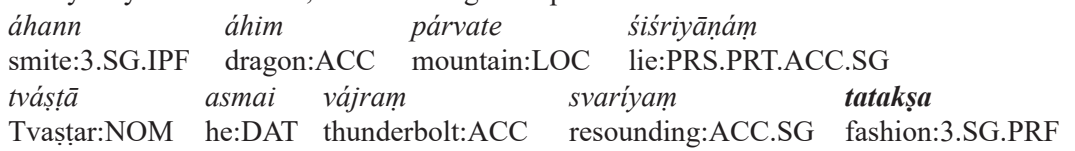

'He smote the dragon which was lying on the mountain, Tvaștar had fashioned the resounding thunderbolt for him' (RV I 32.2) 


\begin{tabular}{lllll} 
etena vai devāh & \multicolumn{2}{c}{ pañcadaśena vajrena } \\
this:INS & truly gods:NOM fifteenfold:INS thunderbolt:INS \\
ebhyo & lokebhyo & asurān & anudanta. \\
These:ABL & worlds:ABL & Asuras:ACC & push:3PL.IPF
\end{tabular}

'The Asuras made strongholds in these worlds, iron in this, silver in the world of the atmosphere golden yonder in the sky they made; the gods when these worlds were surrounded saw the fifteenfold thunderbolt (...) By means of this fifteenfold thunderbolt the gods pushed away the Asuras from these worlds' (KB VIII 9.1-10, cf. Keith 1920)

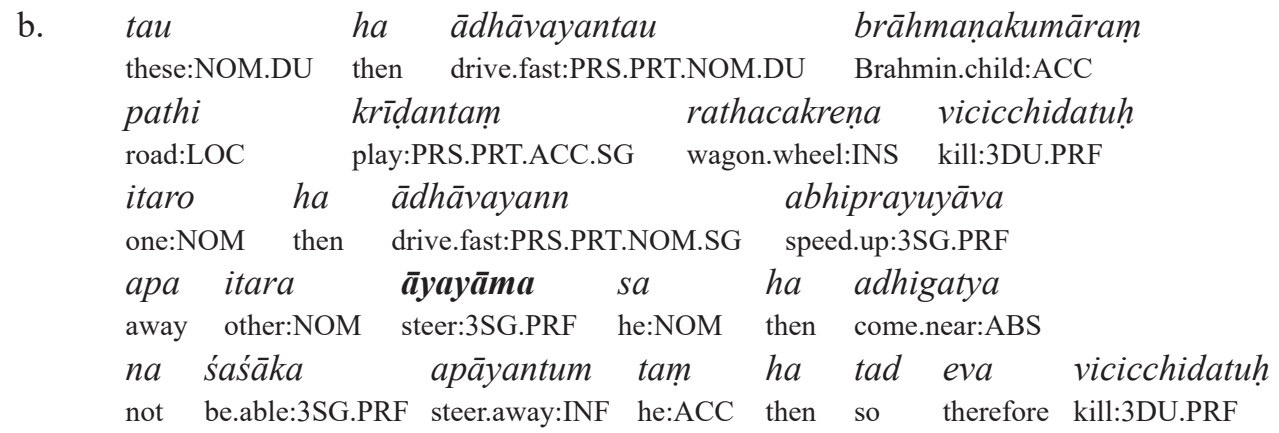

'Once, when the two of them were driving fast they killed a Brahmin child who was playing in the road with the wheel of the wagon. One of them was speeding up, driving fast, while the other was trying to steer away. Having come too close, he was not able to steer away and so they killed him' (JB III 94)

The fact that certain texts from this period only sporadically show Perfect Indicative forms in narrative contexts, while others systematically use this category in this type of context, is a clear indication of system change. As suggested elsewhere (Dahl 2009b; 2014), the gradual development of the Perfect Indicative from a non-narrative to a narrative tense may be understood in terms of conventionalization of pragmatic implicature. Specifically, it was noted above that the Early Vedic Perfect Indicative was compatible with an inferential or indirect evidential reading, as illustrated by the indirect question in (16e), repeated here as (21a) for convenience. Significantly, Perfect Indicative forms are used in similar contexts in later stages of the language as well, as illustrated by the Middle Vedic example in (21b).

$\begin{array}{llllllll}\text { (21) a. } & \text { tán } & \text { no } & \text { ví } & \text { voco } & \text { yádi } & \text { te } & \text { purá } \\ & \text { that:ACC } & \text { we:ACC } & \text { apart } & \text { say:2SG.AOR.INJ } & \text { if } & \text { you:GEN previously } \\ & \text { cij } & \text { jaritấra } & \text { ănaśúh } & \text { sumnám } & \text { indra } & \\ & \text { even } & \text { singers:NOM } & \text { reach:3PL.PRF } & \text { benevolence:ACC } & \text { Indra:VOC }\end{array}$

'Tell us now, whether even the singers of old reached your benevolence, o Indra' (RV VI 22.4ab)

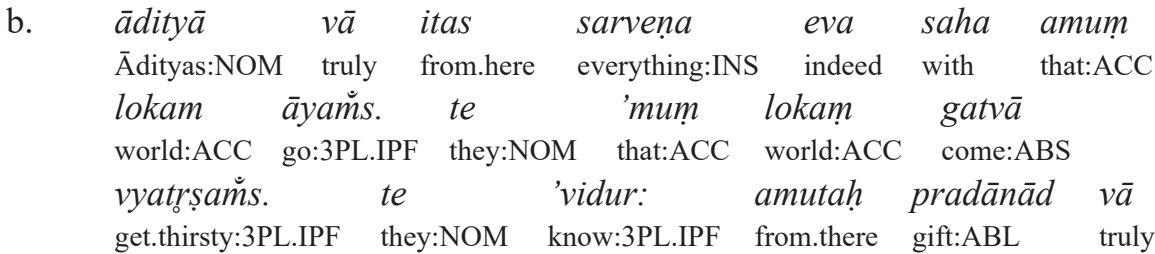




\section{iha äjagāma iti.}

here come:3SG.PRF

'The àdityas went out from here with everything to that world. When they had come to that world, they became thirsty. Then they knew: "it (the thirst) has come here from that gift from there"' (KS IX 3)

The admittedly brief outline of the development of the Vedic Perfect Indicative given in this section suggests that it first went through a development from a present anterior to a past neutral category, two levels of change that were argued to involve a simplification or generalization of its temporal and aspectual semantics. It was noted previously that the Early Vedic Imperfect had a general past neutral semantics and this would lead us to assume that the first phase in the development of the Vedic Perfect Indicative resulted in a competition between these two categories. Although the available sources do not give as much information about this process as one might wish, it is tempting to understand the Middle Vedic and Late Middle Vedic developments as the outcome of a competition along these lines, where the Perfect Indicative, which had an inferential implicature among its reading already at an early stage, is gradually generalized as the main expression in narrative contexts where the speaker talks about situations outside his own sphere of experience.

\subsection{The development of the Vedic Imperfect}

In some respects, the Vedic Imperfect is more diachronically stable than the Aorist Indicative and the Perfect Indicative. Above all, the Imperfect appears to maintain a general past time reference and a neutral aspectual reference throughout the various chronological stages of Vedic, as illustrated by the Middle Vedic and Late Middle Vedic examples in (22). (22) a.

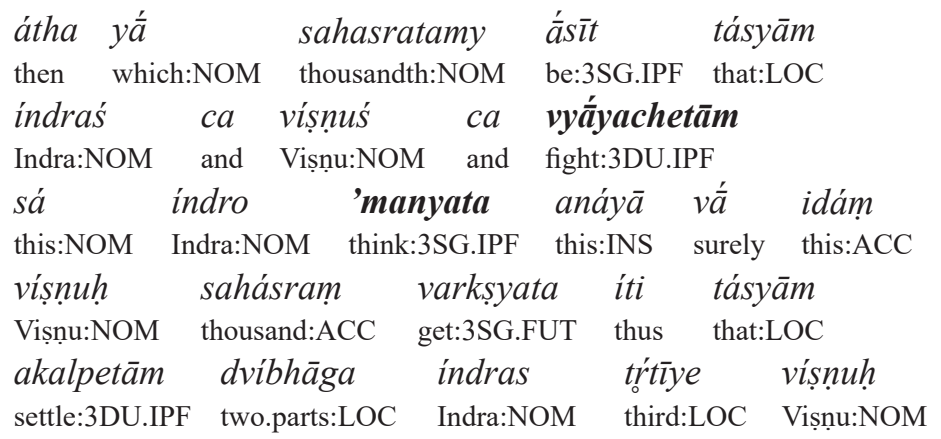

'Then it was the thousandth (part), for which Indra and Viṣṇu were striving. Indra thought "In this way, Viṣnu will surely get (all) the thousand (parts)". They settled in this, that Indra should get two parts and Viṣnu should get the third' (TS ${ }^{\mathrm{P}}$ VII 1.5.5)

\begin{tabular}{|c|c|c|c|c|}
\hline $\begin{array}{l}\text { prajāpatir } \\
\text { Prajāpati:NOM }\end{array}$ & $\begin{array}{l}v \bar{a} v a \\
\text { just }\end{array}$ & $\begin{array}{l}\text { agra } \\
\text { beginning:LOC }\end{array}$ & $\begin{array}{l}\bar{a} s \bar{l} t \\
\text { be:3SG.IPF }\end{array}$ & $\begin{array}{l}\text { so } \\
\text { he:NOM }\end{array}$ \\
\hline $\begin{array}{l}\text { 'kāmayata } \\
\text { wish:3SG.IPF }\end{array}$ & $\begin{array}{l}\text { bahuh } \\
\text { many:NOM }\end{array}$ & $\begin{array}{l}\text { syāṃ } \\
\text { be:1SG.PRS.OPT }\end{array}$ & $\begin{array}{l}\text { prajāyeya } \\
\text { procreate:1SG. }\end{array}$ & \\
\hline $\begin{array}{l}\text { bhūmānaṃ } \\
\text { multitude:ACC }\end{array}$ & $\begin{array}{l}\text { gaccheyam } \\
\text { come:1SG.OPT }\end{array}$ & $\begin{array}{lll}\text { iti } & \text { sa } & \text { tapo } \\
\text { thus } & \text { he } & \text { penan }\end{array}$ & $\begin{array}{r}\text { tap } \\
\text { nce:ACC unde }\end{array}$ & $\begin{array}{l}\text { ata } \\
\text { go:3SG.l }\end{array}$ \\
\hline
\end{tabular}




\section{$\begin{array}{lll}\text { sa } & \text { vācam } & \text { asrjata } \\ \text { he:NOM } & \text { speech:ACC } & \text { emit:3SG.IPF }\end{array}$}

'Prajapati was (alone) here in the beginning. He wished: "May I be many, may I procreate, may I arrive at a multitude". He underwent penance. He emitted the goddess of speech' (JB II 252)

We may observe a number of changes in the temporal reference of the Imperfect, however. Being the main or 'unmarked' morphological past tense, its use is gradually restricted by the Aorist Indicative and Perfect Indicative. For example, while Imperfect forms are found in recent past contexts in Early Vedic and Early Middle Vedic, as illustrated by the examples in (23a) and (23b), respectively, there are no examples of Imperfect forms in this kind of contexts from Middle Vedic onwards.

(23) a.

$\begin{array}{llll}\text { táva } \sim \text { ahám adyá } & \text { maghavann } & \text { úpastutau } \\ \text { you:GEN } & \text { I:NOM today } & \text { great:VOC } & \text { celebration:LOC } \\ \text { dhátar } & \text { vídhātah } & \text { kaláśām } & \text { abhakșayam // } \\ \text { creator:VOC } & \text { distributer:VOC } & \text { waterpots:ACC } & \text { drink:1.SG.IPF }\end{array}$

'In my celebration of you today, o great creator, o distributer I drank from the waterpots' (RV X 167.3cd after Dahl 2010: 189)

b.

\begin{tabular}{llll} 
sūpasthá & \multicolumn{1}{c}{ adyá devó } & vánaspátir abhavad \\
good.place.for.rest.NOM today god.NOM forest.lord.NOM become:3SG..IPF & fón \\
aśvíbhyām chàgena sárasvatyai & meșéna indrāya rșabhéna \\
Aśvins:DAT he.goat:INS Sarasvati:DAT & ram:INS Indra:DAT bull:INS
\end{tabular}

'Today the divine lord of the forest (the sacrificial post) became a good place of rest for the Aśvins through (the slaughtering of) the he-goat, for Sarasvati through (the slaughtering of) the ram and for Indra through (the slaughtering of) the bull' (VSM XXI 60)

Given what has been said earlier in this paper, it is tempting to connect the fact that Imperfect forms gradually become excluded from recent past contexts with the fact that the Aorist Indicative tends to be restricted to exactly this type of context, a development which was suggested to reflect the conventionalization of a pragmatic implicature. Specifically, the Aorist Indicative gradually develops a semantically rather specific recent past time reference and therefore tends to be selected and to become obligatory in contexts of this type, thus blocking the semantically more general Imperfect from such contexts. Moreover, it was noted that the Imperfect is gradually replaced by the Perfect Indicative in narrative contexts referring to events outside of the sphere of experience of the speaker, a development which appears to take place in Late Middle Vedic. These developments result in a system where the distribution of the Imperfect is restricted to non-immediate past contexts within the experience of the speaker, whereas the Aorist Indicative is used in recent/immediate past contexts within the experience of the speaker and the Perfect Indicative is used in contexts beyond the experience of the speaker, as illustrated by the examples in (4), repeated here for convenience.

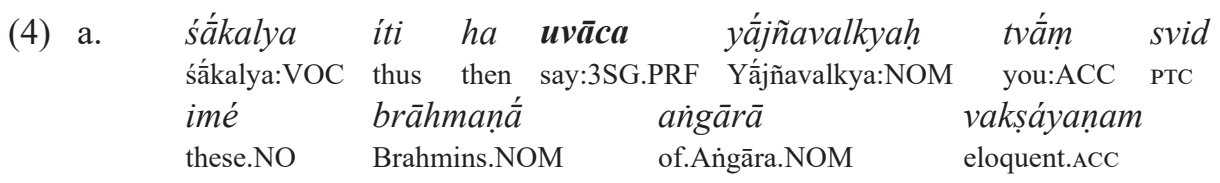




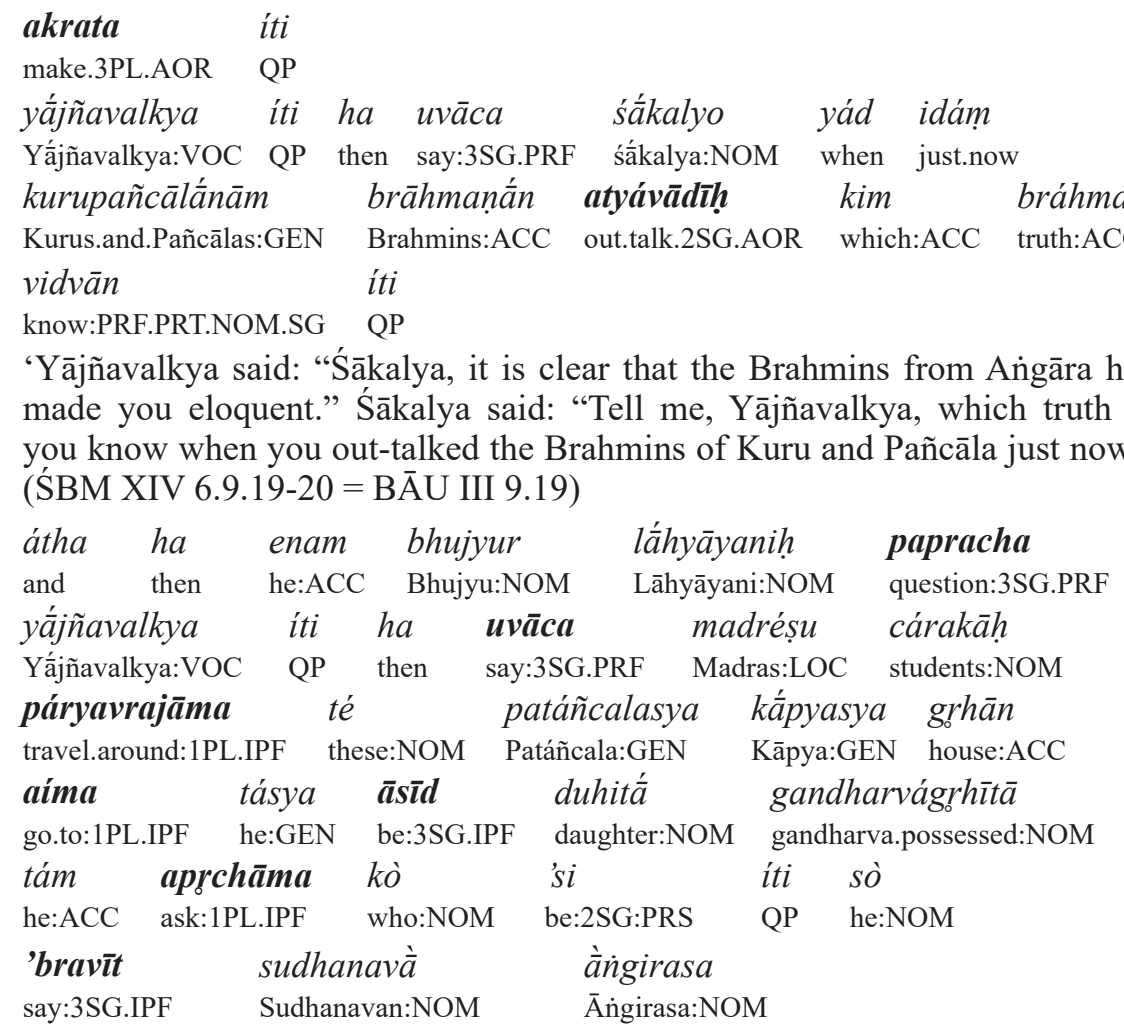

"Then Bhujyu Lāhyāyani began to question him. "Yājñavalkya" he said, "once, when we traveled around in the land of the Madras as itinerant students, we visited the home of Patañcala Kāpya. He had a daughter possessed by a Gandharva. We asked him who he was and, and the Gandharva said that he was Sudhanavan Āngirasa"' (ŚBM XIV 6.3.1 = BĀU III 3.1 after Olivelle 1996)

These observations suggest that the development of the Vedic past tense system involves a general shift from aspect to tense and evidentiality but that the markedness relations remain stable. Future research will establish whether this development is language specific or whether it represents a more general tendency in the world's languages.

\section{Summary}

The discussion in the previous sections has shown that a modified Reichenbachian framework of the type outlined in Section 3 represents a powerful tool for exploring semantic differences between tense/aspect categories both in a synchronic and in a diachronic perspective. By drawing on a relatively rich set of possible relations between the four parameters, the model is able to capture a number of fine-grained semantic properties that serve to delimit the temporal and aspectual reference of the Aorist Indicative, Perfect Indicative and Imperfect at the various stages of Vedic. As a result, one attains a fairly precise picture of the development of the past tense system in this language and, more generally, at a more precise 
understanding of the shift from aspect to tense which is often observed across languages. Specifically, the present analysis of the Vedic data shows that this type of development may be of dual origin. First, it may involve a development from general to specific temporal reference, resulting in the emergence of the unmarked, as it were, on the level of aspectual reference. This is the case in the history of the Vedic Aorist, where we observe a development that represents a sequence of small, discrete changes in its temporal reference leading towards a recent past time reference, while its perfective aspectual reference remains stable until Late Middle Vedic, where it occurs with markedly imperfective readings, suggesting that it has developed a neutral aspectual reference. The present analysis of the data suggest that the development of a more specific temporal reference causally precedes the development of a more general aspectual reference in such cases, something that would be expected given that a fully grammaticalized recent past category should be compatible with any type of aspectual reference. Second, the shift from aspect to tense may involve a development from specific to general time reference, resulting in the simultaneous loss of a specific aspectual reference. This is the case in the history of the Perfect, where we observe a development from specific, retrospective present to simple past on the level of temporal reference, arguably involving the loss of the inference that reference time includes speech time as its last subinterval. We noted that the Perfect had acquired a neutral aspectual reference already by the Early Middle Vedic period, a development involving the loss of the implication that event time may precede reference time, which was speculated to be caused by a general ban on more than two relations of the same type in the same predication. However, after this simplification of its temporal and aspectual reference, the Perfect gradually developed into an inferential past category, something that again may be regarded as the entrenchment of what was once a context-dependent reading. Finally, the Imperfect is a diachronically stable elsewhere category, the distribution of which is delimited by the two other, more specific categories through the various stages of Vedic.

\section{Conclusion}

In this paper I have explored how an essentially synchronic framework can be accommodated to diachronic data with reference to the development of the Vedic past tense system. While some of the specific claims made here may give rise to some controversy and surely will be in need of modification as more data is taken into consideration, I hope to have shown that a multidimensional time-relational framework of the type outlined in this paper provides a fruitful point of departure for the exploration of semantic change in corpus languages.

\section{References}

Bary, Corien. 2009. Aspect in Ancient Greek. A semantic analysis of the aorist and imperfective. Radboud Universiteit Nijmegen. (PhD dissertation.)

Bloomfield, Maurice. 1897. Hymns of the Atharva-veda. Oxford: Clarendon.

Bybee, Joan \& Dahl, Östen. 1989. The creation of tense and aspect systems in the languages of the world. Studies in Language 13(1). 51-103. 
Bybee, Joan \& Perkins, Revere \& Pagliuca, William. 1994. The Evolution of Grammar. Chicago: University of Chicago Press.

Chierchia, Gennaro \& McConnell-Ginet, Sally. 2000. Meaning and Grammar. An Introduction to Semantics. Cambridge, MA: MIT Press.

Dahl, Eystein. 2008. Performative Sentences and the Morphosyntax-Semantics Interface in Early Vedic. Journal of South Asian Linguistics 1. 7-27.

Dahl, Eystein. 2009a. Some Semantic and pragmatic aspects of object alternation in Old Vedic. In Barðdal, Jóhanna \& Chelliah, Shobana (eds.), The Role of Semantics and Pragmatics in the Development of Case, 23-55. Amsterdam: Benjamins.

Dahl, Eystein. 2009b. Semantische und pragmatisch-kontextuelle Faktoren in der Entwicklung des altindoarischen Perfekts. In Rieken, Elisabeth \& Widmer, Paul (eds.), Pragmatische Kategorien. Form, Funktion und Diachronie. Akten der Arbeitstagung der Indogermanischen Gesellschaft in Marburg, 24.-26.9.2007, 35-50. Wiesbaden: Reichert.

Dahl, Eystein. 2009c. Reconstructing Inflectional Semantics: The Case of the Proto-Indo-European Imperfect. In Jamison, Stephanie W. \& Melchert, H. Craig \& Vine, Brent (eds.), Proceedings of the 20th Annual UCLA Indo-European Conference, 37-52. Bremen: Ute Hempen Verlag.

Dahl, Eystein. 2010. Time, Tense and Aspect in Early Vedic Grammar. Exploring Inflectional Semantics in the Rigveda. Leiden: Brill.

Dahl, Eystein. 2012. Evidence for Evidentiality in Late Vedic. In Klein, Jared \& Yoshida, Kazuhiko (eds.), Indic across the Millennia: from Rigveda to Modern Indo-Aryan. 14th World Sanskrit Conference, Kyoto, Japan, September 1-5 2009. Proceedings of the Linguistics Section, 9-23. Bremen: Ute Hempen Verlag.

Dahl, Eystein. 2013. Typological change in Vedic: The development of the Aorist from a Perfective Past to an Immediate Past. In Josephson, Folke \& Söhrman, Ingemar (eds.), Diachronic and Typological Perspectives on Verbs, 261-298. Amsterdam: Benjamins.

Dahl, Eystein. 2014. The Development of the Vedic Perfect: From Anterior to Inferential Past. In Klein, Jared \& Tucker, Elizabeth (eds.), Vedic and Sanskrit Historical Linguistics: Papers from the 13th World Sanskrit Conference, 179-242. New Dehli: Motilal Banarshidas.

Dahl, Östen. 1984. Temporal distance: remoteness distinctions in tense-aspect systems. In Butterworth, Brian \& Comrie, Bernhard \& Dahl, Östen (eds.), Explanations for Language Universals, 105-121. Berlin: Mouton.

Dahl, Östen. 1985. Tense and Aspect Systems. Oxford: Blackwell.

Delbrück, Berthold. 1876. Altindische Tempuslehre. Halle a. S.: Verlag der Buchhandlung des Waisenhauses.

Delbrück, Berthold. 1888. Altindische Syntax. Halle a. S.: Verlag der Buchhandlung des Waisenhauses.

Delbrück, Berthold. 1897. Vergleichende Syntax der indogermanischen Sprachen. Zweiter Theil. Strassburg: Trübner.

Eberle, Kurt \& Kasper, Walter. 1994. French past tenses and temporal structure. In Thieroff, Rolf \& Ballweg, Joachim (eds.), Tense System in European Languages, 149-172. Tübingen: Niemeyer.

Eckardt, Regine. 2006. Meaning Change in Grammaticalization. An Enquiry into Semantic Reanalysis. Oxford: Oxford University Press.

Fintel, Kai von. 1995. The formal semantics of grammaticalization. In: Beckman, Jill M. (ed.), Proceedings of the Annual Meeting of the North East Linguistics Society (NELS) 25(2), 175-189. GLSA, Department of Linguistics, Umass at Amherst.

Hopper, Paul J. \& Traugott, Elizabeth Closs. 2003. Grammaticalization. Cambridge: Cambridge University Press.

Jamison, Stephanie W. 1993. Natural History Notes on the Rigvedic 'Frog' Hymn. Annals of the Bhandarkar Oriental Research Institute 72-73. 138-144.

Kamp, Hans \& Reyle, Uwe. 1993. From Discourse to Logic. Introduction to Modeltheoretic Semantics of Natural Language, Formal Logic and Discourse Representation Theory. Dordrecht: Kluwer.

Kiparsky, Paul. 1998. Aspect and Event Structure in Vedic. In Singh, Rajendra (ed.), The Yearbook of South Asian Languages and Linguistics 1998. New Dehli-Thousand Oaks-London: Sage Publications.

Kiparsky, Paul. 2002. Event Structure and the Perfect. In Beaver, David I. \& Casillas Martínez, Luis D. \& Clark, Brady Z. \& Kaufmann, Stefan (eds.), The Construction of Meaning. Stanford, CA: CSLI Publications.

Kiparsky, Paul. 2005. The Vedic Injunctive: Historical and synchronic implications. In: The Yearbook of South Asian Languages and Linguistics 2005. New Dehli-Thousand Oaks-London: Sage Publications.

Klein, Jared. 1978. The Particle $u$ in the Rigveda. A Synchronic and Diachronic Study. Göttingen: Vandenhoeck and Ruprecht.

Klein, Wolfgang. 1995. A Time-Relational Analysis of Russian Aspect. Language 71. 669-695. 
Kratzer, Angelica. 1998. More Structural Analogies between Pronouns and Tenses. In Strolovitch, Devon \& Lawson, Aaron (eds.), Proceedings of SALT VII, 92-110. Ithaca: Cornell University Press.

Krifka, Manfred. 1998. The origins of telicity. In Rothstein, Susan (ed.), Events and Grammar, 197-235. Dordrecht: Kluwer.

Kulikov, Leonid. 2013. Language vs. grammatical tradition in Ancient India: How real was Pāṇinian Sanskrit? Evidence from the history of late Sanskrit passives and pseudo-passives. Folia Linguistica Historica 34. 59-91.

Olivelle, Patrick. 1996. Upanișads. A new translation by Patrick Olivelle. New York: Oxford University Press.

Portner, Paul H. 2007. Imperatives and Modals. Natural Language Semantics 15. 351-383.

Reichenbach, Hans. 1947. Elements of Symbolic Logic. London: Macmillan.

Schaden, Gerhard. 2009. Present perfects compete. Linguistics and Philosophy 32. 115-141.

Schaden, Gerhard. 2012. Modelling the "Aoristic Drift of the Present Perfect" as Inflation An Essay in Historical Pragmatics. International Review of Pragmatics 4. 261-292.

Smith, Carlota. 1997. The Parameter of Aspect. Second Edition. Dordrecht: Kluwer.

Smith, Carlota. 2003. Modes of Discourse. Cambridge: Cambridge University Press.

Traugott, Elizabeth Closs \& Dasher, Alan B. 2005. Regularity in Semantic Change. Cambridge: Cambridge University Press.

Whitney, William Dwight. 1905. Atharva-Veda Samhita translated with a critical and exegetical commentary (2 Volumes). Cambridge MA: Harvard University Press.

Witzel, Michael. 1989. Tracing the vedic dialects. In Caillat, Colette (ed.), Dialectes dans les langues indoaryennes, 97-265. Paris: College de France, Institut de Civilisation Indienne.

Witzel, Michael. 1995. Early Indian History: Linguistic and Textual Parameters. In: Erdosy, G. (ed.), Language, Material Culture and Ethnicity. The Indo-Aryans of Ancient South Asia, 85-125. Berlin-New York: de Gruyter. 